Gredičak M; Matanović I; Zimmermann B \& Jerić I. "Bergman Cyclization of Acyclic Amino Acid Derived Enediynes Leads to the Formation of 2,3-Dihydrobenzo[f]isoindoles", Journal of Organic Chemistry, Vol.75, No.18, pp. 6219-6228. DOI: 10.1021/jo101302n

\title{
Bergman Cyclization of Acyclic Amino Acid Derived Enediynes Leads to the Formation of 2,3-Dihydrobenzo[f]isoindoles
}

\author{
Matija Gredičak †, Ivana Matanović †, Boris Zimmermann †, and Ivanka Jerić $* \dagger$ \\ $\uparrow$ Division of Organic Chemistry and Biochemistry and $\ddagger$ Division of Physical Chemistry \\ Ruđer Bošković Institute, Bijenička 54, Zagreb, 10000-HR Croatia
}

ijeric@irb.hr

Received July 2, 2010, Published online August 18, 2010

DOI: $10.1021 /$ jo101302n

URL: http://pubs.acs.org/doi/full/10.1021/jo101302n

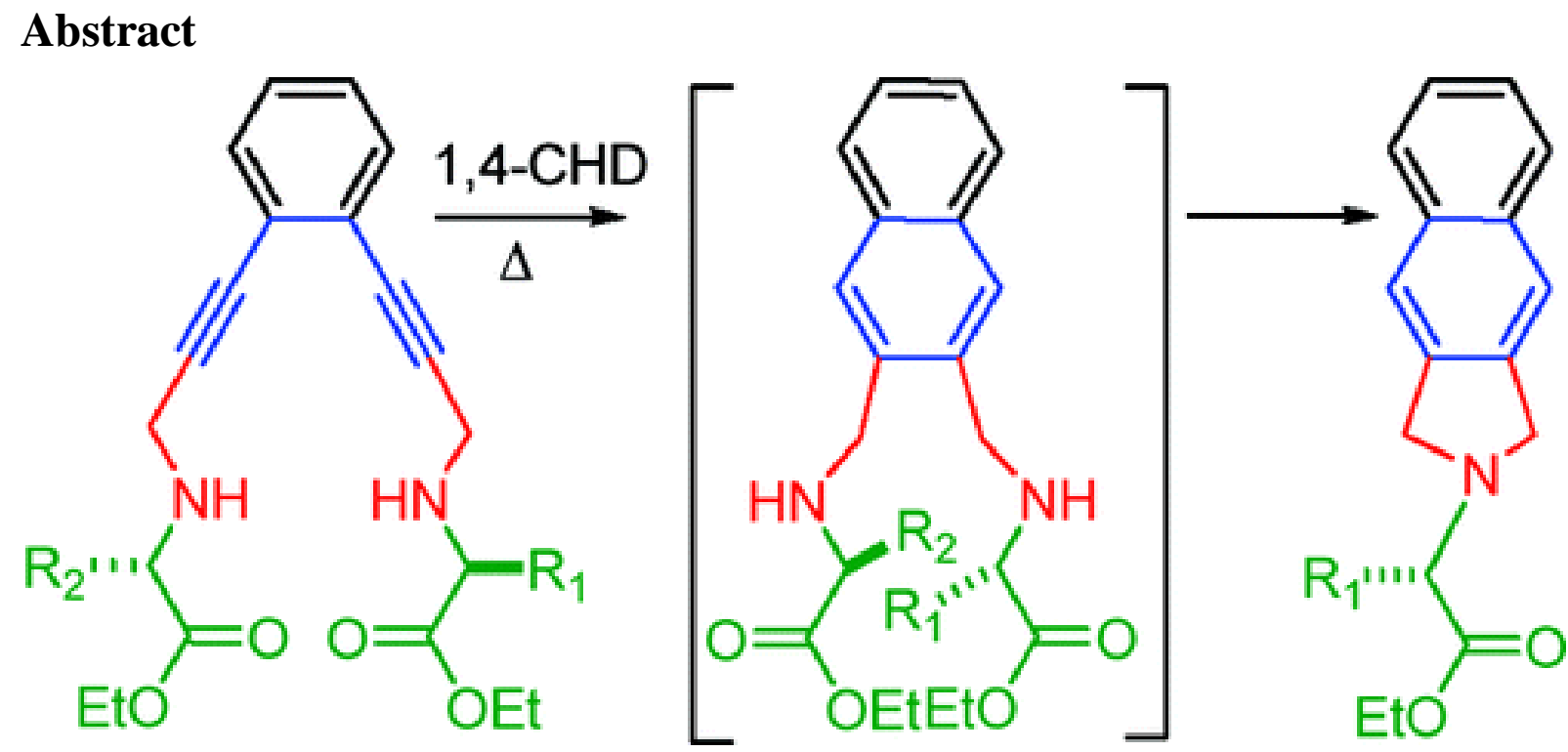

Enediyne-peptide conjugates are recently recognized as useful tools in targeting various proteins, while the mechanism underlying the observed activity remains somewhat unclear. Addressing these issues, we have prepared acyclic amino acid derived enediynes and disclosed a novel thermally induced cyclization-elimination pathway. Initial formation of 1,4-benzene diradical and $\mathrm{H}$-atom abstraction from an external donor is followed by $\mathrm{S}_{\mathrm{N}} 2$ substitution leading to 2,3-dihydrobenzo[f]isoindoles. The proposed mechanism is supported by experimental and computational data. Additionally, we showed that amino acid side chains, although placed three bonds away from acetylene terminuses, have an appreciable influence on the reactivity of studied enediynes. These results demonstrate that amino acid or peptide parts of enediyne-peptide conjugates cannot be considered as recognition elements exclusively but may also participate in various reactions through amine functionality. 
Gredičak M; Matanović I; Zimmermann B \& Jerić I. "Bergman Cyclization of Acyclic Amino Acid Derived Enediynes Leads to the Formation of 2,3-Dihydrobenzo[f]isoindoles", Journal of Organic Chemistry, Vol.75, No.18, pp. 6219-6228. DOI: 10.1021/jo101302n

\section{Introduction}

Knowledge gathered in the field of enediyne chemistry has greatly influenced research in different areas of organic chemistry, spectroscopy, and material-oriented chemistry. Isolated from soil bacteria in the 1980 s, enediyne compounds soon became recognized as important synthetic targets from numerous points of view. Antitumor properties of naturally occurring enediynes are attributed to the embedded enediyne ((Z)-3-hexene-1,5-diyne) moiety.(1) After initial triggering through intramolecular nucleophilic addition, the enediyne group undergoes Bergman cyclization (BC).(2) Stabilization of thus formed 1,4-benzene diradical is achieved by the abstraction of two protons from the DNA backbone, resulting in the cleavage of the DNA and consequently death of a cell. Total syntheses of natural enediynes brought solutions for many challenging molecular architectures and made a distinct contribution to the progress of synthetic methodologies.(3-6) Apart from their biological activity, enediynes are key building blocks in the synthesis of helical polycyclic aromatic hydrocarbons, interesting due to their optical and electronic properties.(7) Also, it was suggested that enediynes are potentially useful mechanophores, stress-sensitive units applied to the synthesis of polymers whose properties can be altered by mechanical energy.(8)

Structural complexity, nonselectivity, and poor stability of natural enediynes urge scientists to find new molecules with advantages of natural occurring ones but having less drawbacks. With this aim, a number of cyclic and acyclic enediyne-related molecules have been prepared and their activity has been tested upon thermal activation,(9) photochemical activation,(10) or complexation with metals.(11)

Our scope of research is the study of acyclic amino acid derived enediynes. Amino acids, as carriers of the enediyne moiety, have multiple advantages: they are good complexation ligands; an array of side chains provides easy change of molecule properties (e.g., lipophilicity, acidity) and versatility of functional groups enables binding of other molecules. Therefore, enediyne-amino acid conjugates are lately recognized as important tools in studies of Bergman cyclization. A series of photoactivated lysine-enediyne conjugates have been used to demonstrate nonrandom double-stranded DNA cleavage and the role of amino acid residue on the selectivity of DNA cleavage.(12) Also, some of these conjugates were capable of recognizing the site of single-stranded DNA cleavage and induce conversion of this damage into double-stranded DNA cleavage. Moreover, the activity of lysine-enediyne conjugates toward $\mathrm{pH}$-controlled light-induced Bergman cyclization was emphasized recently.(12) It was shown that enediyne-amino acid conjugates effectively target $\alpha$ chymotrypsin and inhibit its activity,(13) while enediyne-(Asp) $)_{3}$ conjugate showed high affinity binding to the $\mathrm{H} 1$ histone, causing its degradation upon photoactivation.(14) Cyclic analogues with an enediyne moiety bonded to the amino acid $\alpha$-carbon have also been reported and their activity evaluated.(15) Contrary to that, our approach was to retain properties of natural amino acids by placing the enediyne moiety at the $\mathrm{N}$-terminus and benefit from the neighboring side chains (compounds $\mathbf{4 a - e}$, Scheme 1). Thus, C-terminuses can be easily modified in defined steps of the synthesis (coupling with amino acids or polyamines to enhance solubility or binding to biomolecules), while the enediyne skeleton will direct conformation of peptide grown on both $\mathrm{C}$-terminuses. We were also driven by the question: can side chains distinctively influence the rate of Bergman cyclization? Here, we answer this question and provide evidence about the process following initial Bergman cyclization. 
Gredičak M; Matanović I; Zimmermann B \& Jerić I. "Bergman Cyclization of Acyclic Amino Acid Derived Enediynes Leads to the Formation of 2,3-Dihydrobenzo[f]isoindoles", Journal of Organic Chemistry, Vol.75, No.18, pp. 6219-6228. DOI: 10.1021/jo101302n

\section{Results and discussion}

\section{Synthesis}

Derivatives $4 \mathbf{a}-\mathbf{e}$ were prepared according to the synthetic path shown in Scheme 1. The Sonogashira coupling of fully protected N-propargylated derivatives of alanine, valine, and leucine 1(16) with 1,2-diiodobenzene was performed in THF in the presence of piperidine, $\mathrm{CuI}$, and $\mathrm{Pd}\left(\mathrm{PPh}_{3}\right)_{4}$. When coupled with an equimolar amount of 1,2-diiodobenzene (Scheme 1, path a), corresponding monosubstituted derivatives $\mathbf{2}$ were obtained in around $50 \%$ yield (slight excess of 1,2-diiodobenzene was used to ensure complete consumption of acetylene component and facilitate purification by column chromatography). Second, Sonogashira coupling with either the same or different derivative 1 gave enediyne-bridged symmetric AlaAla (3a), Val-Val (3b), Leu-Leu (3c), and asymmetric Ala-Val (3d) and Val-Gly (3e) sequences in good yields. Symmetric enediynes $\mathbf{3 a}-\mathbf{c}$ were also prepared according to path $b$, by coupling of $\mathbf{1}$ with 1.2 equiv of 1,2-diiodobenzene. Deprotection of $O$ nitrobenzenesulfonyl group (oNbs) with $\mathrm{PhSH}$ and $\mathrm{K}_{2} \mathrm{CO}_{3}$ in DMF gave aromatic enediynes 4 in good yields. All compounds were characterized by NMR spectroscopy, mass spectrometry, HRMS, and FT-IR spectroscopy (Experimental Section).

\section{SCHEME 1. Synthetic Path to $4 a-e^{a}$}

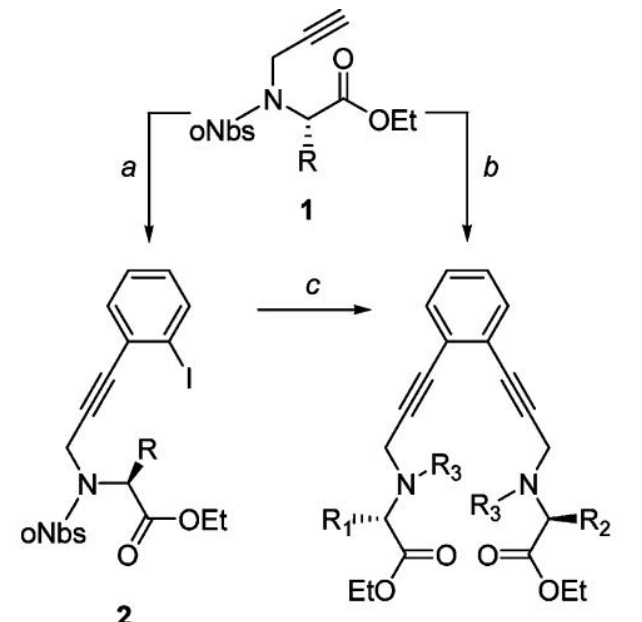

2

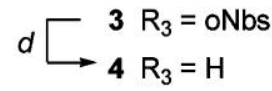

\begin{tabular}{|c|c|c|c|}
\hline Compound & $\mathbf{R}_{1}$ & $\mathbf{R}_{\mathbf{2}}$ & Yield $/ \%^{\mathrm{b}}$ \\
\hline 4a (Ala-Ala) & $-\mathrm{CH}_{3}$ & $-\mathrm{CH}_{3}$ & 38 \\
\hline 4b (Val-Val) & & & 32 \\
\hline 4c (Leu-Leu) & & & 33 \\
\hline 4d (Ala-Val) & $-\mathrm{CH}_{3}$ & & 19 \\
\hline $4 \mathrm{e}$ (Val-Gly) & & & 18 \\
\hline
\end{tabular}

${ }^{a}$ Reagents and conditions: (a) $o-\mathrm{C}_{6} \mathrm{H}_{4} \mathrm{I}_{2}(3.6 \mathrm{mmol})$, piperidine $(3 \mathrm{mmol}), \mathrm{CuI}(0.3 \mathrm{mmol}), \mathrm{Pd}\left(\mathrm{PPh}_{3}\right)_{4}$ (0.03 mmol) in THF, $30 \mathrm{~min}$, then 1 (3 mmol) and piperidine $(3 \mathrm{mmol})$ in THF, $2 \mathrm{~h}$; (b) $o-\mathrm{C}_{6} \mathrm{H}_{4} \mathrm{I}_{2}(0.5$ mmol), piperidine $(1 \mathrm{mmol})$, $\mathrm{CuI}(0.1 \mathrm{mmol})$, $\mathrm{Pd}\left(\mathrm{PPh}_{3}\right)_{4}(0.01 \mathrm{mmol})$ in THF, $30 \mathrm{~min}$, then 1 (1 mmol) and piperidine, $10 \mathrm{~h}$; (c) 2 (1 mmol), piperidine $(1 \mathrm{mmol}), \mathrm{CuI}(0.1 \mathrm{mmol})$, and $\mathrm{Pd}\left(\mathrm{PPh}_{3}\right)_{4}$ (0.01 mmol) in THF, $30 \mathrm{~min}$, then $1(1 \mathrm{mmol})$ and piperidine (1 mmol), $10 \mathrm{~h}$; (d) $3(0.5 \mathrm{mmol}), \mathrm{K}_{2} \mathrm{CO}_{3}$ (1 mmol) and PhSH (1 mmol), DMF, $1 \mathrm{~h}$.

Overall yields; two reaction steps for $\mathbf{4 a - 4 c}$ and three reaction steps for $\mathbf{4} \mathbf{d}$ and $\mathbf{4 e}$. 
Gredičak M; Matanović I; Zimmermann B \& Jerić I. "Bergman Cyclization of Acyclic Amino Acid Derived Enediynes Leads to the Formation of 2,3-Dihydrobenzo[f]isoindoles", Journal of Organic Chemistry, Vol.75, No.18, pp. 6219-6228. DOI: 10.1021/jo101302n

\section{Reactivity of Enediynes 4a-e}

Thermal reactivity of enediyne compounds toward the Bergman cyclization is traditionally studied by the differential scanning calorimetry (DSC). It can provide information about onset and maximum temperatures and activation energies of a certain process. However, DCS results have to be interpreted with caution when numerous side reactions occur, capable of lowering activation barriers.(17) Also, the exact structural changes accompanying the process cannot be determined by DSC. Contrary to that, temperature-dependent FT-IR spectroscopy is an established method for simple and rapid monitoring of thermally induced physical and chemical rearrangements that simultaneously provide temperature values and insight into structural changes.(18) IR spectra of enediynes $\mathbf{4 a}-\mathbf{a}$ have characteristic vibrational bands of ester and amine groups. The most prominent bands are associated with $\mathrm{N}-\mathrm{H}$ stretching (3340 $\left.\mathrm{cm}^{-1}\right), \mathrm{C}=\mathrm{O}$ stretching $\left(1730 \mathrm{~cm}^{-1}\right)$, and $\mathrm{C}-\mathrm{O}-\mathrm{C}$ stretching $\left(1190 \mathrm{~cm}^{-1}\right)$, and they can be used for tracking structural changes within the molecule. The weak band at $2225 \mathrm{~cm}^{-1}$ is associated with $\mathrm{C} \equiv \mathrm{C}$ stretching vibrations and is essential for monitoring the Bergman cyclization by FT-IR technique. The FT-IR measurements performed within the temperature range of $20-250{ }^{\circ} \mathrm{C}$ are consistent for all five enedyines and indicate that a chemical process occurs at approximately $170{ }^{\circ} \mathrm{C}$ (Figure 1). Disappearance of an acetylene band at $2225 \mathrm{~cm}^{-1}$ is in accordance with anticipated Bergman cycloaromatization. However, substantial intensity changes of all spectral bands and disappearance of the amine band at $3340 \mathrm{~cm}^{-1}$ point toward additional or parallel chemical processes occurring.

\section{FIGURE 1.}

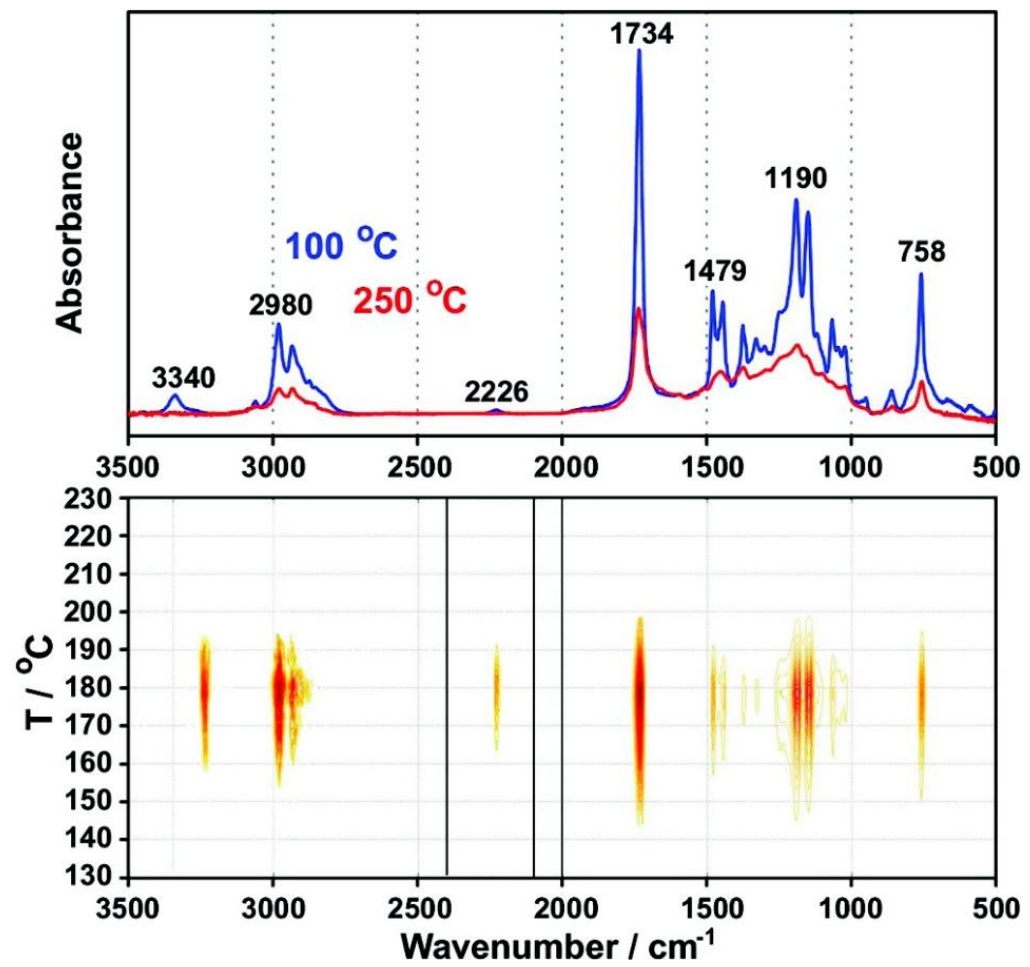

Temperature-dependent FT-IR measurement of 4a (Ala-Ala): FT-IR spectra at 100 and $250{ }^{\circ} \mathrm{C}$ (top); MW 2D IR correlation analysis as contour plot of the baseline-corrected data (bottom) (analyzed spectral regions, 4000-2400, 2300-2100, 2000-400 $\mathrm{cm}^{-1}$; window, 10 spectra; window step, 1 spectrum; heating rate, $1 \mathrm{~K} \mathrm{~min}^{-1}$; resolution, $4 \mathrm{~cm}^{-1}$; number of scans per spectrum, 10). 
Gredičak M; Matanović I; Zimmermann B \& Jerić I. "Bergman Cyclization of Acyclic Amino Acid Derived Enediynes Leads to the Formation of 2,3-Dihydrobenzo[f]isoindoles", Journal of Organic Chemistry, Vol.75, No.18, pp. 6219-6228. DOI: 10.1021/jo101302n

Onset temperatures of cycloaromatization (the temperatures at which process begins), obtained by baseline analysis (see Supporting Information for more details), vary significantly with respect to the bulkiness of side chains (Table 1). Comparison of symmetric compounds $\mathbf{4 a}, \mathbf{4 b}$, and $\mathbf{4 c}$ (alanine, valine, and leucine side chains, respectively) revealed the temperature difference of $30{ }^{\circ} \mathrm{C}$ between compounds $4 \mathbf{a}$ and 4c. It was demonstrated previously that properties of substituents at the terminal acetylenes may contribute significantly to the reactivity of enediynes.(19) Here, it is evident that substituents placed even three bonds away from reactive centers have a considerable influence on the cyclization process. In this respect, we were interested at looking at asymmetric derivatives $\mathbf{4 d}$ and 4e. Although not notable, somewhat lower onset temperatures for both compounds can be explained most likely by better spatial accommodation of unequal side chains.

TABLE 1. Results of the FT-IR Measurements of Enediynes $4 a-4 e^{a}$

\begin{tabular}{ccc}
\hline compound & $T_{\text {onset }} /{ }^{\circ} \mathrm{C}$ & $T_{\max } /{ }^{\circ} \mathrm{C}$ \\
\hline 4a & 130 & 175 \\
4b & 135 & 185 \\
$\mathbf{4 c}$ & 160 & 210 \\
$\mathbf{4 d}$ & 125 & 175 \\
$\mathbf{4 e}$ & 125 & 175
\end{tabular}

${ }^{a}$ Measurements were performed within the temperature range of 20-250 ${ }^{\circ} \mathrm{C}$ under atmospheric pressure and at the heating rate of $1 \mathrm{~K} \mathrm{~min}^{-1}$.

\section{Isolation and Characterization of Products}

The next step was performing Bergman cyclization in solution and isolation of products. Cycloaromatization of $\mathbf{4 a}$ was performed with 10 equiv of 1,4-cyclohexadiene (1,4-CHD) in DMF at $175{ }^{\circ} \mathrm{C}$ (Scheme 2). Reaction mixture was checked by TLC and after $8 \mathrm{~h}$ shows consumption of starting compound. ${ }^{13} \mathrm{C}$ NMR spectrum of isolated and purified product showed disappearance of acetylenic carbons, a new signal in the aromatic region, and a large downfield shift of $\mathrm{CH}_{2}$ carbon adjacent to the acetylene (from 37.6 to 55.4 ppm). The ${ }^{1} \mathrm{H}$ NMR spectrum pointed toward a symmetric molecule with six aromatic protons and only one alanine moiety attached. Also, mass spectrum showed a signal at $\mathrm{m} / \mathrm{z} 270$ but not $\mathrm{m} / \mathrm{z} 387$ corresponding to the Bergman product 5a. Looking at the fragmentation patterns of the molecular $[\mathrm{M}+\mathrm{H}]^{+}$ions of both $4 \mathbf{a}$ and the product, we noticed that the $[\mathrm{M}+\mathrm{H}]^{+}$ion at $\mathrm{m} / \mathrm{z} 270$ and its product ions at $\mathrm{m} / \mathrm{z}, 155$ and 196 represent $2 \mathrm{Da}$ mass gain to the product ions of $4 \mathbf{a}(\mathrm{m} / \mathrm{z} 268,153$, and 194) (Figure 2). In the MS/MS spectrum of the molecular $[\mathrm{M}+\mathrm{H}]^{+}$ion $\mathrm{m} / \mathrm{z} 385$ of $\mathbf{4 a}$, the presence of product ion at $\mathrm{m} / \mathrm{z} 268$ corresponds to the elimination of alanine residue (117 Da). 
Gredičak M; Matanović I; Zimmermann B \& Jerić I. "Bergman Cyclization of Acyclic Amino Acid Derived Enediynes Leads to the Formation of 2,3-Dihydrobenzo[f]isoindoles", Journal of Organic Chemistry, Vol.75, No.18, pp. 6219-6228. DOI: 10.1021/jo101302n

SCHEME 2. Bergman Cyclization of 4 (10 equiv of 1,4-CHD, DMF, $\Delta$ )(20)
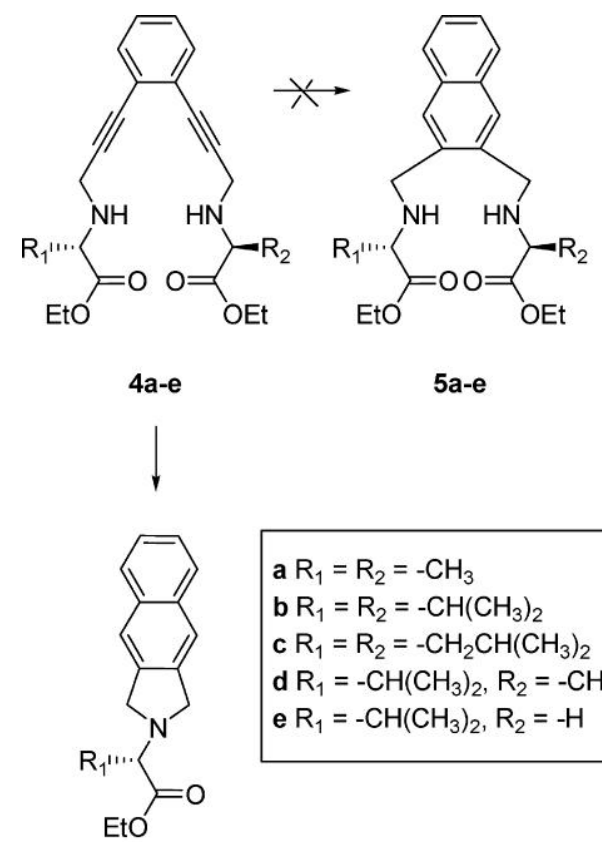

a $\mathrm{R}_{1}=\mathrm{R}_{2}=-\mathrm{CH}_{3}$

b $\mathrm{R}_{1}=\mathrm{R}_{2}=-\mathrm{CH}\left(\mathrm{CH}_{3}\right)_{2}$

c $\mathrm{R}_{1}=\mathrm{R}_{2}=-\mathrm{CH}_{2} \mathrm{CH}\left(\mathrm{CH}_{3}\right)_{2}$

d $\mathrm{R}_{1}=-\mathrm{CH}\left(\mathrm{CH}_{3}\right)_{2}, \mathrm{R}_{2}=-\mathrm{CH}_{3}$

e $\mathrm{R}_{1}=-\mathrm{CH}\left(\mathrm{CH}_{3}\right)_{2}, \mathrm{R}_{2}=-\mathrm{H}$

6a-c

FIGURE 2. MS/MS spectra of the molecular $[\mathrm{M}+\mathrm{H}]^{+}$ions of $4 \mathrm{a}$ and $6 \mathrm{a}$.
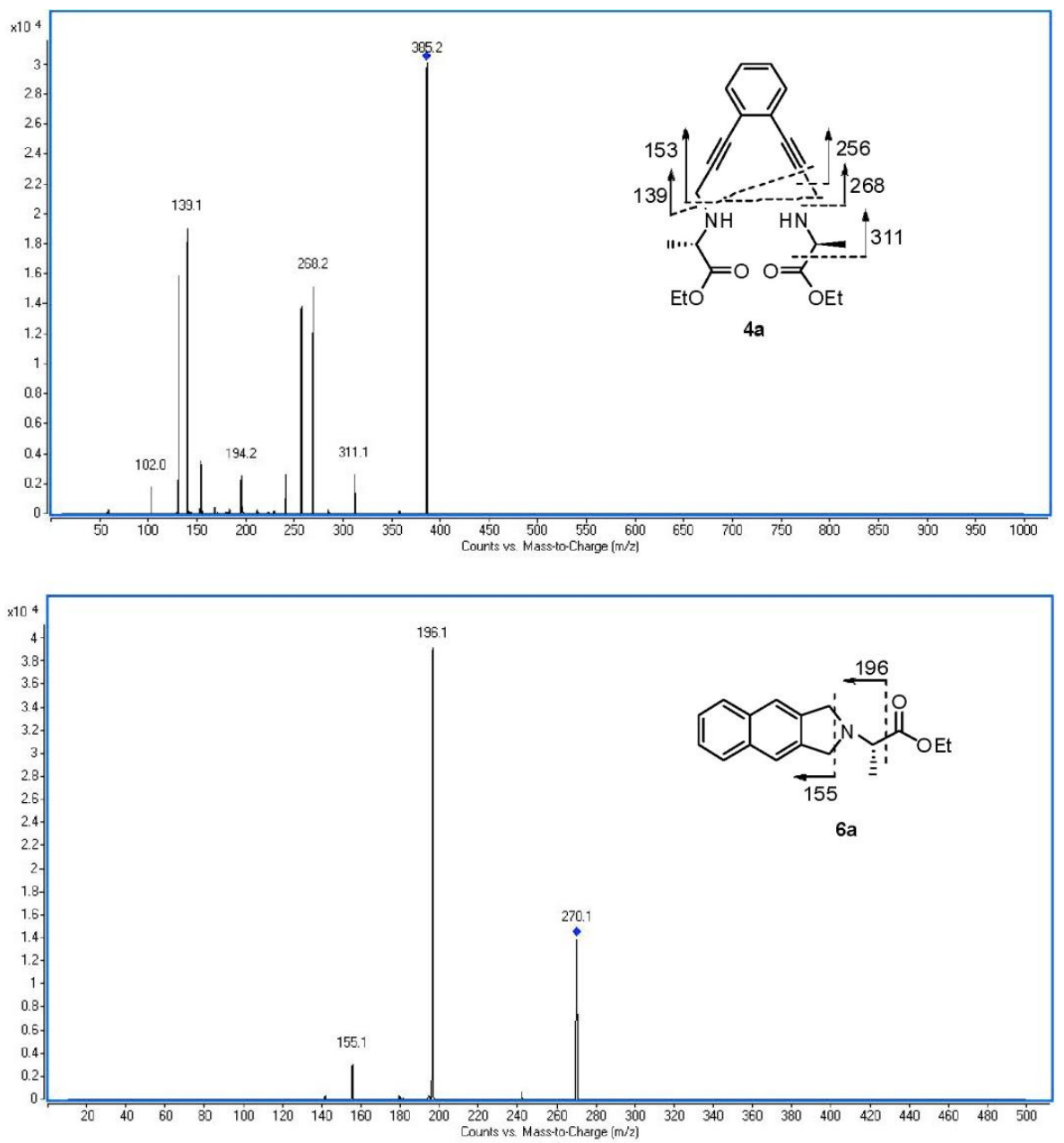
Gredičak M; Matanović I; Zimmermann B \& Jerić I. "Bergman Cyclization of Acyclic Amino Acid Derived Enediynes Leads to the Formation of 2,3-Dihydrobenzo[f]isoindoles", Journal of Organic Chemistry, Vol.75, No.18, pp. 6219-6228. DOI: 10.1021/jo101302n

All together, FT-IR, NMR, and MS analysis undoubtedly confirmed the structure of 2,3dihydrobenzo $[f]$ isoindole 6a. The very same result was obtained with other two symmetric derivatives, $\mathbf{4 b}$ and $\mathbf{4 c}$. Formation of isoindoles was accompanied by polymerization reactions (poorly soluble material) that account for low yields of isolated products (around 20\%). It was demonstrated previously by using IR, solid-state NMR, UV-vis spectroscopy, and MS that formation of different polymer products in the Bergman cycloaromatization reaction of simple aromatic enediyne can be explained by a set of intermolecular radical reactions.(21)

Isoindole-related compounds are not unknown in enediyne chemistry; they have been obtained from the cobalt complex of a strained nine-membered enediyne ring.(22) Upon deprotection, this compound underwent a spontaneous Bergman cyclization at $0{ }^{\circ} \mathrm{C}$. Benzo[f]isoindoles display some interesting properties; they are farnesyl transferase inhibitors(23) and EP4 receptor agonists.(24) To the best of our knowledge, this is the first example of isoindoles obtained by the Bergman cyclization of acyclic enediynes.

Two paths of the mechanism, both of them based on $S_{N} 2$, are possible (Scheme 3). In path $A$, the amino group of one amino acid performs nucleophilic attack on the methylene carbon atom placed between acetylene and the amino group of the second amino acid. Newly formed nine-membered ring is highly unstable and spontaneously undergoes Bergman cyclization resulting in 6. In path $\mathrm{B}$, Bergman cyclization is the first step; it brings amines closer, facilitating $\mathrm{S}_{\mathrm{N}} 2$ attack. Methylene carbon atom placed between acetylene and the amino group (path A) or attached to the aromatic ring (path B) is deficient in electrons and, consequently, susceptible to nucleophilic attack. To prove which path is genuine, $4 \mathbf{a}$ was heated under the same conditions as before, but without 1,4-CHD. If path A is probable, then the result should be decomposition of substrate since nine-membered rings are extremely unstable(19) and there is no $\mathrm{H}$-atom donor to quench the Bergman diradical. If the mechanism goes by path $\mathrm{B}$, the substrate should remain intact. After $48 \mathrm{~h}$ of heating, substrate 4a remains intact based on TLC and MS and was quantitatively retrieved. Furthermore, it survived heating up to $240{ }^{\circ} \mathrm{C}$ for the same time period. This led us to conclude that the formation of the isoindole derivative takes place through path $\mathrm{B}$, the Bergman cyclization followed by intramolecular nucleophilic substitution with consequent amino acid elimination.(25) 
Gredičak M; Matanović I; Zimmermann B \& Jerić I. "Bergman Cyclization of Acyclic Amino Acid Derived Enediynes Leads to the Formation of 2,3-Dihydrobenzo[f]isoindoles", Journal of Organic Chemistry, Vol.75, No.18, pp. 6219-6228. DOI: 10.1021/jo101302n

\section{SCHEME 3. Two Possible Mechanism Paths to 6}

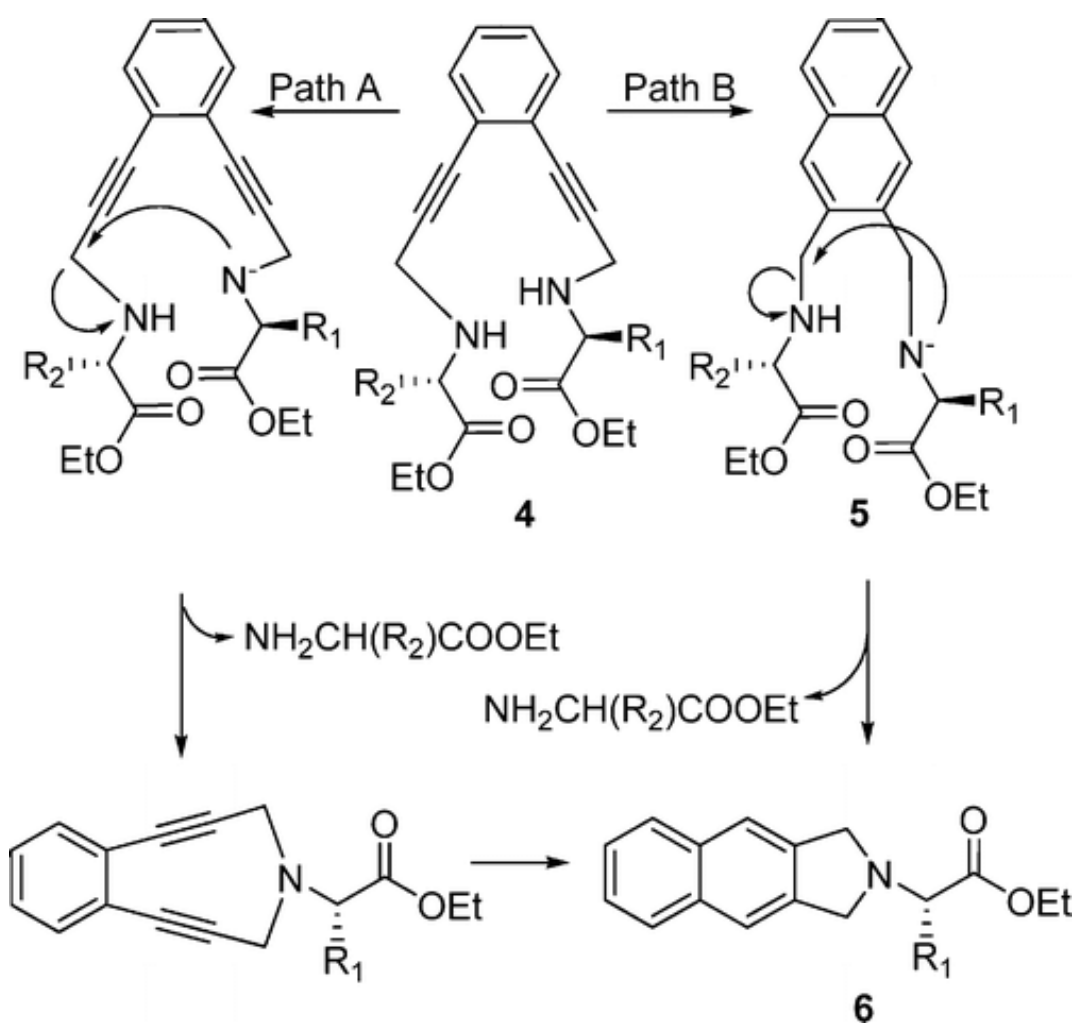

Additional support was searched from quantum chemistry approaches as a complement to experimental studies. Gas phase geometries of intermediates, transition states, reactants, and products in paths $\mathrm{A}$ and $\mathrm{B}$ for the formation of isoindole-related compounds were obtained using the density functional theory (DFT) with the UB3LYP(26) and UBLYP(27) exchangecorrelation functional and the $6-31 \mathrm{G}(\mathrm{d}, \mathrm{p})$ basis set as implemented in the Gaussian03 quantum chemical software package.(28) Computed energy profiles for two paths are shown in Figures 3 and 4. As proposed above, the first step in path B is the formation of a diradical followed by two hydrogen abstraction steps from the 1,4-CHD as a $\mathrm{H}$-atom donor. The activation barrier for the cyclization step is calculated to be $37.2 \mathrm{kcal} / \mathrm{mol}$ at the UB3LYP/6$31 \mathrm{G}(\mathrm{d}, \mathrm{p})$ level of theory and $29.1 \mathrm{kcal} / \mathrm{mol}$ at the UBLYP/6-31G(d,p) level (Figure 3a). The energy of the transition state is just slightly above the energy of the diradical intermediate, which is less stable for $36.2 \mathrm{kcal} / \mathrm{mol}(27.10 \mathrm{kcal} / \mathrm{mol}$ at UBLYP/6-31G(d,p) level) than the enediyne reactant $4 \mathbf{a}$. Calculated energy of diradicals should be regarded with care as it is known that higher multiconfigurational levels of theory are needed to accurately describe multiconfigurational electronic structure of singlet diradicals.(29) However, an unrestricted broken-symmetry approach has proven to be a practical tool for the study of enediyne and enyne-allene cyclizations, $(30,31)$ and thus the UDFT method should provide a correct qualitative picture of a Bergman cyclization process. Two highly exothermic hydrogen abstraction steps follow the endothermic cyclization with energy gains of 56.1 and 38.1 $\mathrm{kcal} / \mathrm{mol}$, and the overall Bergman cycloaromatization is an exothermic process. Unfortunately, all attempts to locate the transition states in the two hydrogen abstraction steps failed and led to either a reactant or product structure. However, previous detailed theoretical 
Gredičak M; Matanović I; Zimmermann B \& Jerić I. "Bergman Cyclization of Acyclic Amino Acid Derived Enediynes Leads to the Formation of 2,3-Dihydrobenzo[f]isoindoles", Journal of Organic Chemistry, Vol.75, No.18, pp. 6219-6228. DOI: 10.1021/jo101302n

studies of the Bergman cyclization mechanism demonstrated that barriers to hydrogen abstraction are only a few $\mathrm{kcal} / \mathrm{mol}$ less than one-tenth of the overall energy change.(30) The second step in path B (Figure $3 b$ ) includes a nucleophilic substitution reaction resulting in the elimination of the amino acid and the formation of isoindole-related product 6a. Here, we should point out that several conformers of the Bergman product 5a, as well as of the enediyne 4a, were located due to the significant floppiness of amino acid chains. The schemes in Figure 4 include only the ones with the largest stability. The most stable conformer of structure 5a is the one in which the $\mathrm{C}-\mathrm{C}-\mathrm{C}-\mathrm{N}$ dihedral angle (in Figure $4 \mathrm{~b}$ denoted with an asterisk) is $2.7^{\circ}$. However, the nucleophilic attack by the amino group on the methylene carbon atom occurs in the conformer with the $\mathrm{C}-\mathrm{C}-\mathrm{C}-\mathrm{N}$ dihedral angle of $56.5^{\circ}$. So, the final step in path $\mathrm{B}$ proceeds only after the rotation of the amino acid backbone around the $\mathrm{C}-\mathrm{C}$ bond by $53.8^{\circ}$. The barrier for this rotation is only $5.3 \mathrm{kcal} / \mathrm{mol}$, while the substitution step has a barrier of $33.3 \mathrm{kcal} / \mathrm{mol}$. In the course of the Bergman cycloaromatization reaction, $58.6 \mathrm{kcal} / \mathrm{mol}$ of energy was released and the overall reaction is still exothermic.

\section{Figure 3. Path B.}

(a)

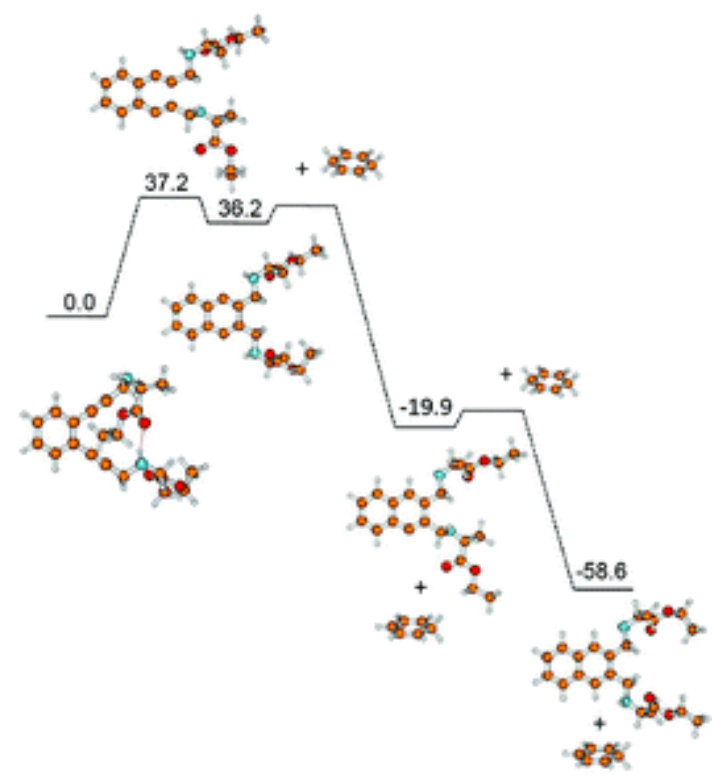

(a) Reaction energy pathway for the Bergman cycloaromatization of enediyne $\quad 4 a \quad$ with $1,4-$ cyclohexadiene as a $\mathrm{H}$-atom donor ending with the Bergman product 5a. (b) Reaction energy pathway for the elimination reaction of Bergman product 5a, giving the isoindole product 6a. All energies are calculated at the UB3LYP/6$31 \mathrm{G}(\mathrm{d}, \mathrm{p})$ level of theory and given

(b)

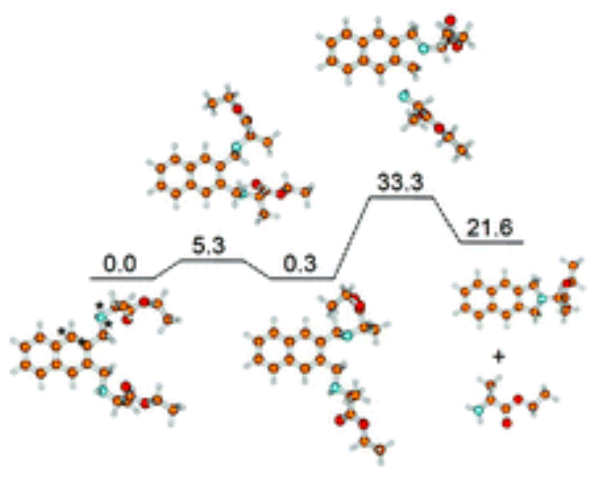
in $\mathrm{kcal} / \mathrm{mol}$ relative to the energy of the $\mathbf{4 a}(\mathrm{a})$ and $\mathbf{5 a}(\mathrm{b})$. 
Gredičak M; Matanović I; Zimmermann B \& Jerić I. "Bergman Cyclization of Acyclic Amino Acid Derived Enediynes Leads to the Formation of 2,3-Dihydrobenzo[f]isoindoles", Journal of Organic Chemistry, Vol.75, No.18, pp. 6219-6228. DOI: 10.1021/jo101302n

In path $\mathrm{A}$, the elimination reaction precedes the Bergman cyclization. The calculated energy barrier for the nucleophilic attack in enediyne $\mathbf{4 a}$ is $42.0 \mathrm{kcal} / \mathrm{mol}$ (Figure 4). The substitution step is followed by the formation of a diradical with the barrier of $17.3 \mathrm{kcal} / \mathrm{mol}$. The diradical formation step is also highly endothermic and thus reversible. We believe that two energetically unfavorable starting steps in path A can explain the experimental finding that 2,3-dihydrobenzo[f]isoindoles form via mechanism B where only one small barrier exists.

Figure 4. Path A. Reaction energy pathway calculated at the UB3LYP/6-31G(d,p) level of theory. All energies are given in $\mathrm{kcal} / \mathrm{mol}$ and relative to the energy of the enediyne $4 \mathbf{a}$.

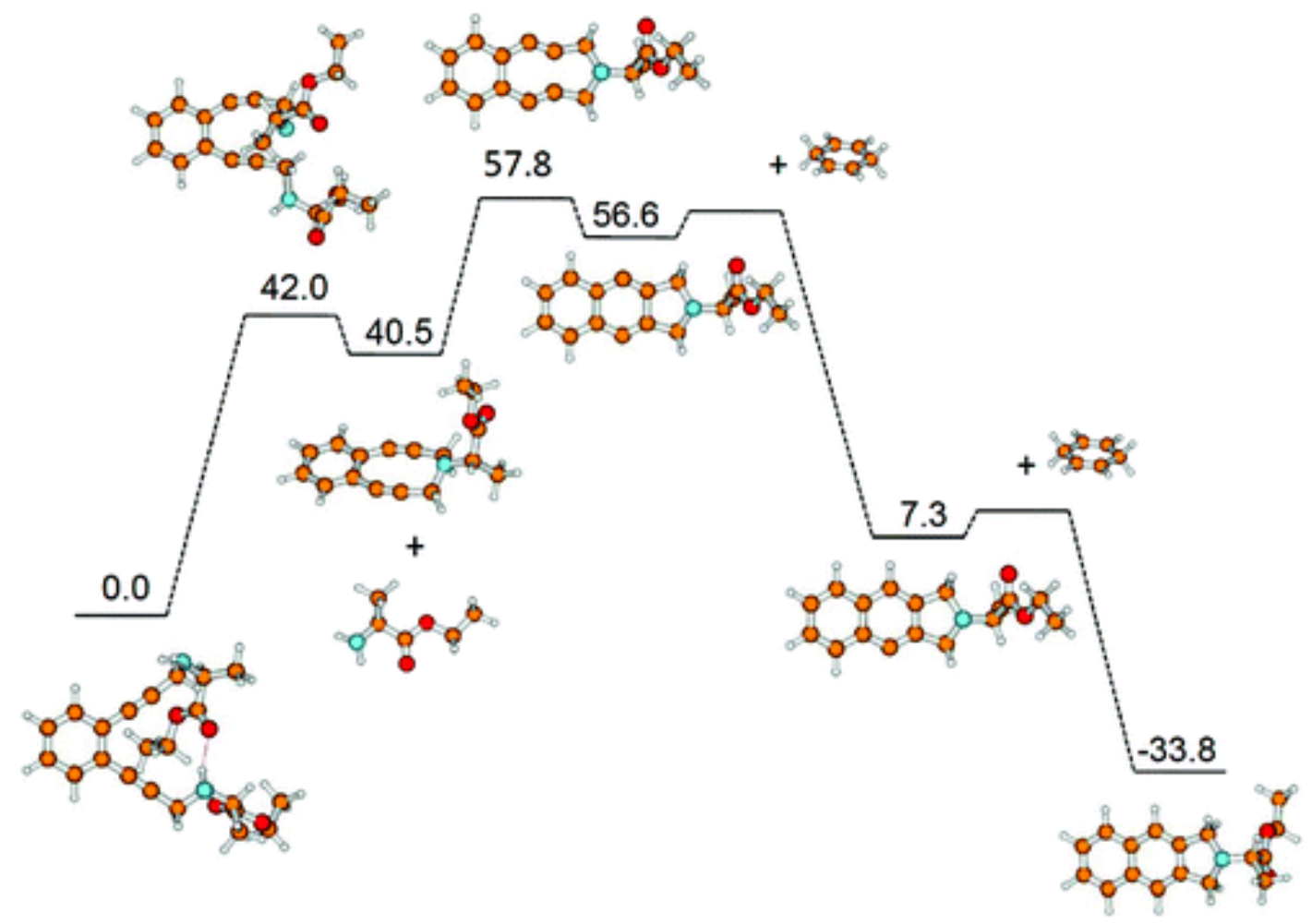

With the cycloaromatization-elimination mechanism of enediynes $4 \mathbf{a}^{-} \mathbf{c}$ proven, we turned our attention to asymmetric derivatives. Therefore, compounds $\mathbf{4 d}$ and $\mathbf{4 e}$ were heated in the presence of 1,4-CHD, and they both yielded (based on TLC and MS) only valine-related isoindole 6b, although in the latter, the major event was decomposition of substrate, accompanied by traces of $\mathbf{6 b}$. Reaction mixture of Ala-Val enediyne $4 \mathbf{d}$ was also checked by HPLC-MS. TIC chromatogram (Figure 5) clearly points to the formation of valine-related isoindole $\mathbf{6 b}\left(R_{\mathrm{T}}=4.82 \mathrm{~min}\right)$, while alanine-related isoindole $\mathbf{6 a}$ is detected only in traces among numerous components eluted at $R_{\mathrm{T}}=2.40 \mathrm{~min}$ (mass spectra shown in Supporting Information). 
Gredičak M; Matanović I; Zimmermann B \& Jerić I. "Bergman Cyclization of Acyclic Amino Acid Derived Enediynes Leads to the Formation of 2,3-Dihydrobenzo[f]isoindoles", Journal of Organic Chemistry, Vol.75, No.18, pp. 6219-6228. DOI: 10.1021/jo101302n

FIGURE 5. TIC chromatogram of the reaction mixture of enediyne $\mathbf{4 d}$.

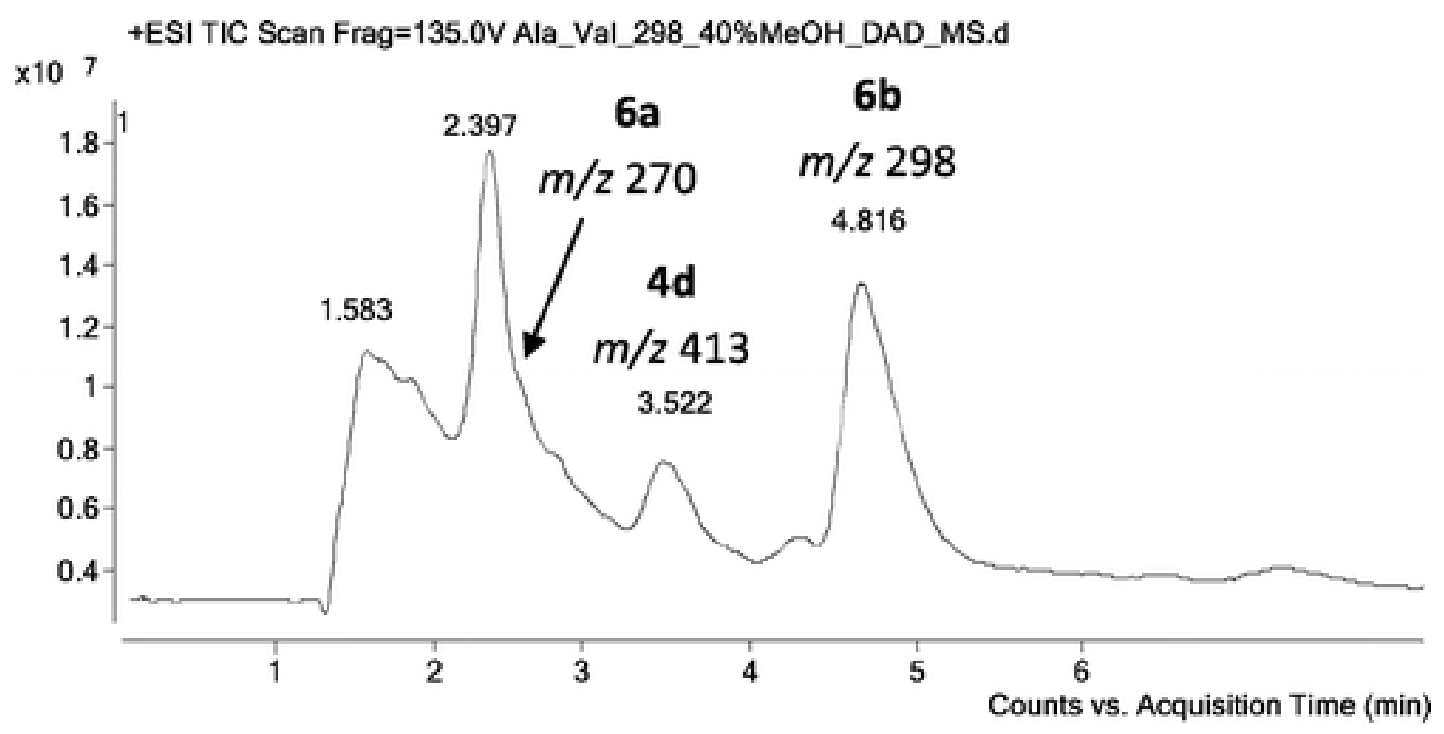

Finally, further insight into cyclization-elimination processes of asymmetric enediynes was sought by using NMR spectroscopy. We were aware of its limitations in this particular case: formation of multiple compounds present in low quantities and polymerization reaction hamper conclusions about kinetics. Therefore, we focused on parallel experiments: enediynes 4a and $4 \mathbf{d}$ were dissolved in deuterated DMF $(0.043 \mathrm{M})$ with 2 equiv of 1,4-CHD and heated at $175{ }^{\circ} \mathrm{C}$. NMR spectra were recorded at different time points (every $5 \mathrm{~h}$ ). If formation of isoindole-related Bergman products $\mathbf{6 a}$ and $\mathbf{6 b}$ is accompanied by the release of H-Ala-OEt, as we have proposed, NMR spectra should reflect this resemblance in the mechanism. Indeed, aliphatic region of spectra recorded after 5 and $10 \mathrm{~h}$ showed the appearance of new signals that can be assigned as $\alpha$ and $\beta$ protons of alanine and $\mathrm{CH}_{3}$ protons of the ethyl ester moiety (Figure 6). Unfortunately, protons of enediynes and products have quite similar chemical shifts in DMF- $d_{7}$; the aromatic part of the spectrum is covered by benzene formed upon proton transfer from 1,4-CHD to the diradical, and formation of numerous products is visible in broadening of the present signals and appearance of new ones, especially after $10 \mathrm{~h}$ of heating. However, the presence of the same pattern in symmetric $\mathbf{4 a}$ and asymmetric enediyne 4d supported our initial findings about products of the Bergman cyclization of asymmetric enediynes.

It is known that branching of the amino acid $\alpha$-carbon atom increases electron density in the system (branched alkanes are better electron donors than linear ones) and makes amine more nucleophilic. Therefore, it is reasonable to assume that increased nucleophilicity of amines carrying branched side chains accounts for the formation valine-related product $\mathbf{6 b}$ with the elimination of amino acid carrying less branched side chains. Of course, two asymmetric derivatives are not enough to allow more than hypothesis, and additional studies are undertaken to bring more general conclusions. 
Gredičak M; Matanović I; Zimmermann B \& Jerić I. "Bergman Cyclization of Acyclic Amino Acid Derived Enediynes Leads to the Formation of 2,3-Dihydrobenzo[f]isoindoles", Journal of Organic Chemistry, Vol.75, No.18, pp. 6219-6228. DOI: 10.1021/jo101302n

Figure 6. Parts of NMR spectra of $\mathbf{4 a}$ and $\mathbf{4 d}$ obtained after heating at $175{ }^{\circ} \mathrm{C}$ at different time points $\left(t_{1}=5 \mathrm{~h}, t_{2}=10 \mathrm{~h}\right)$.

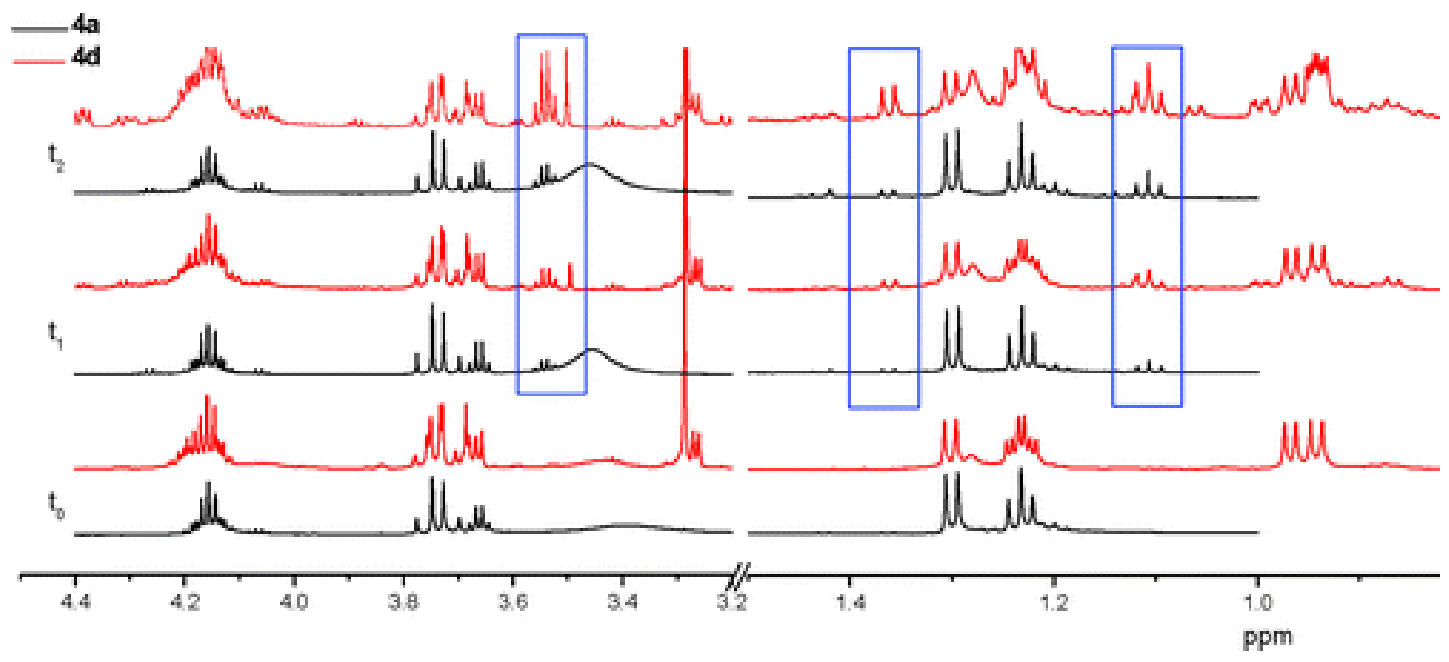

It is known that branching of the amino acid $\alpha$-carbon atom increases electron density in the system (branched alkanes are better electron donors than linear ones) and makes amine more nucleophilic. Therefore, it is reasonable to assume that increased nucleophilicity of amines carrying branched side chains accounts for the formation valine-related product $\mathbf{6 b}$ with the elimination of amino acid carrying less branched side chains. Of course, two asymmetric derivatives are not enough to allow more than hypothesis, and additional studies are undertaken to bring more general conclusions.

Enediyne-derived 1,4-diyl radical can react in several ways; abstraction of protons from DNA is only one of them. It has been proposed that self-decomposition of C-1027 includes $\mathrm{H}$ abstraction from apoprotein and subsequent formation of glycyl radical.(32) Glycyl radical can further undergo different reactions, depending on environment, leading to peptide scission, formation of cross-linking, or adducts. Therefore, formation of diyl radical can be considered as a trigger for numerous fragmentation and rearrangement reactions. Recently, a detailed study on model enediynes mimicking members of esperamicine and calchiamicine families revealed the importance of intramolecular $\mathrm{H}$-atom abstraction and provided evidence about different products formed, depending on reaction conditions and substitution pattern.(33) Our results made a contribution to an array of Bergman cyclization products and had some enlightening new moments. Absence of an external $\mathrm{H}$-atom donor hampers both cyclization and fragmentation in enediynes $\mathbf{4 a}-\mathbf{e}$, contrary to enediynes bearing tetrahydropyran and tetrahydrofuran rings, where fragmentation products were detected in $30-40 \%$ yields.(32) However, the amino acid moiety took part in a further process, nucleophilic substitution reaction. Formation of 2,3-dihydrobenzo[f]isoindoles triggered by the Bergman cyclization is the first such example and raises questions about reactivity and the role of amino groups in enediyne-peptide conjugates. Addressing these questions is important in light of recent increased usage of such conjugates in targeting proteins instead of DNA. $(13,14)$ 
Gredičak M; Matanović I; Zimmermann B \& Jerić I. "Bergman Cyclization of Acyclic Amino Acid Derived Enediynes Leads to the Formation of 2,3-Dihydrobenzo[f]isoindoles", Journal of Organic Chemistry, Vol.75, No.18, pp. 6219-6228. DOI: 10.1021/jo101302n

\section{Conclusion}

In summary, we have synthesized a series of acyclic amino acid derived enediynes and tested them under conditions of the Bergman cyclization. FT-IR analysis clearly showed that the bulkiness of the amino acid side chain increases the temperature of the Bergman reaction and also indicated significant structural changes during the process. Experimental and computational data support the mechanism comprising cycloaromatization followed by the nucleophilic substitution with subsequent amino acid elimination yielding 2,3dihydrobenzo[f]isoindoles. Also, the structure of amino acid determines the structure of isoindole formed. The influence of amine properties on the formation of 2,3dihydrobenzo $[f]$ isoindoles and the importance of activation energies and amino acid side chain will be investigated to better understand the mechanism. Finally, the presented results opened two important subjects: (a) amino acids with different side chains can be considered for fine-tuning of reactivity, especially in unstable enediyne systems, due to the established correlation between bulkiness and onset temperature of Bergman cyclization; and (b) reactivity and participation of amino groups in reactions following initial Bergman cyclization is to be taken into account when dealing with enediyne-peptide conjugates.

\section{Experimental section}

The synthesis and characterization data of products are provided below. Synthesis and characterization of amino acid derivatives 1 have been published previously.(16) For further details on general methods, computational details, FT-IR, NMR, and MS spectra, consult the Supporting Information.

\section{General Procedure for the Synthesis of 2}

1,2-Diiodobenzene $(3.6 \mathrm{mmol})$, piperidine $(3 \mathrm{mmol}), \mathrm{CuI}(0.3 \mathrm{mmol})$, and $\mathrm{Pd}\left(\mathrm{PPh}_{3}\right)_{4}(0.03$ mmol) are mixed in THF under argon at room temperature for $30 \mathrm{~min}$. 1 (3 mmol) and piperidine ( $3 \mathrm{mmol}$ ) are mixed in THF under argon and added dropwise to the initial solution. The solution is stirred until all substrate is consumed, approximately $2 \mathrm{~h}$. Solvent is evaporated and the product extracted with EtOAc, washed with brine and water, and purified by flash column chromatography.

(oNbs)[3-(2-Iodophenyl)propargyl]-l-alanine ethyl ester (2a):

Yield $911 \mathrm{mg}(56 \%)$ (yellow oil); $R_{f} 0.71$ (petrol ether/EtOAc 2:1); [ $\left.\alpha_{\mathrm{D}}\right]-45.0$ (c 1.0, EtOAc); ${ }^{1} \mathrm{H}$ NMR $\left(600 \mathrm{MHz}, \mathrm{CDCl}_{3}\right) \delta 8.25-8.23(\mathrm{~m}, 1 \mathrm{H}, \mathrm{H} 3 \mathrm{oNbs}), 7.79-7.77(\mathrm{~m}, 1 \mathrm{H}, \mathrm{H} 6$ oNbs), 7.65-7.60 (m, 3H, H3 2-iodophenyl; H4, H5 oNbs), 7.26-7.24 (m, 2H, H5, H6 2iodophenyl), 7.00-6.97 (m, 1H, H4, 2-iodophenyl), 4.87 (q, $1 \mathrm{H}, \alpha$ Ala, $\left.{ }^{3} J_{\alpha \beta}=7.4 \mathrm{~Hz}\right), 4.40$, $4.74\left(\mathrm{~d}, 2 \mathrm{H}, \mathrm{CH}_{2}\right.$ propargyl, $\left.{ }^{2} J_{\mathrm{HH}}=18.7 \mathrm{~Hz}\right), 4.12\left(\mathrm{q}, 2 \mathrm{H}, \mathrm{CH}_{2} \mathrm{OEt},{ }^{3} J_{\mathrm{HH}}=7.2 \mathrm{~Hz}\right), 1.74(\mathrm{~d}$, $\left.3 \mathrm{H}, \beta \mathrm{Ala},{ }^{3} J_{\alpha \beta}=7.4 \mathrm{~Hz}\right), 1.20\left(\mathrm{t}, 3 \mathrm{H}, \mathrm{CH}_{3} \mathrm{OEt},{ }^{3} J_{\mathrm{HH}}=7.2 \mathrm{~Hz}\right) ;{ }^{13} \mathrm{C}$ NMR $\left(150 \mathrm{MHz}, \mathrm{CDCl}_{3}\right)$ $\delta 170.8$ (CO Ala), 147.5 (C2 oNbs), 138.2 (C3 2-iodophenyl), 133.5 (C1 oNbs), 132.4, 133.0 (C6 2-iodophenyl, C3 oNbs), 131.1, 131.3 (C4, C5 oNbs), 128.3 (C1 2-iodophenyl), 127.2, 129.9, (C4, C5 2-iodophenyl), 123.8 (C6 oNbs), 99.8 (C2 2-iodophenyl), 87.5 (C2 propargyl), 86.1 (C3 propargyl), $61.1\left(\mathrm{CH}_{2} \mathrm{OEt}\right), 55.5$ ( $\alpha$ Ala), 35.1 (C1 propargyl), 16.4 ( $\beta$ Ala), $13.5\left(\mathrm{CH}_{3} \mathrm{OEt}\right)$; HRMS (MALDI) $\mathrm{m} / z[\mathrm{M}+\mathrm{K}]^{+}$calcd for $\mathrm{C}_{20} \mathrm{H}_{19} \mathrm{IN}_{2} \mathrm{O}_{6} \mathrm{SK}, 580.9640$; found 580.9639 . 
Gredičak M; Matanović I; Zimmermann B \& Jerić I. "Bergman Cyclization of Acyclic Amino Acid Derived Enediynes Leads to the Formation of 2,3-Dihydrobenzo[f]isoindoles", Journal of Organic Chemistry, Vol.75, No.18, pp. 6219-6228. DOI: 10.1021/jo101302n

(oNbs)[3-(2-Iodophenyl)propargyl]-l-valine ethyl ester (2b):

Yield $775 \mathrm{mg}(45 \%)$ (yellow oil); $R_{f} 0.59$ (petrol ether/EtOAc 2:1); $\left[\alpha_{\mathrm{D}}\right]-40.0$ (c 0.5 , EtOAc); ${ }^{1} \mathrm{H}$ NMR $\left(300 \mathrm{MHz}, \mathrm{CDCl}_{3}\right) \delta 8.24-8.22$ (m, 1H, $\left.\mathrm{H} 3 \mathrm{oNbs}\right), 7.84-7.80(\mathrm{~m}, 1 \mathrm{H}, \mathrm{H} 6$ oNbs), 7.66-7.60 (m, 3H, H3 2-iodophenyl; H4, H5 oNbs), 7.35-7.26 (m, 2H, H5, H6 2iodophenyl), 7.04-6.98 (m, 1H, H4, 2-iodophenyl), 4.69, $4.72\left(\mathrm{~d}, 2 \mathrm{H}, \mathrm{CH}_{2}\right.$ propargyl, ${ }^{2} J_{\mathrm{HH}}=$ $18.6 \mathrm{~Hz}), 4.27\left(\mathrm{~d}, 1 \mathrm{H}, \alpha \mathrm{Val},{ }^{3} J_{\alpha \beta}=10.3 \mathrm{~Hz}\right), 4.04\left(\mathrm{q}, 2 \mathrm{H}, \mathrm{CH}_{2} \mathrm{OEt},{ }^{3} J_{\mathrm{HH}}=7.1 \mathrm{~Hz}\right)$, 2.53-2.41 (m, $1 \mathrm{H}, \beta \mathrm{Val}), 1.12\left(\mathrm{t}, 3 \mathrm{H}, \mathrm{CH}_{3} \mathrm{OEt},{ }^{3} J_{\mathrm{HH}}=7.1 \mathrm{~Hz}\right), 1.04,1.14\left(\mathrm{~d}, 6 \mathrm{H}, \gamma \gamma^{\prime} \mathrm{Val}\right.$, $\left.{ }^{3} J_{\beta \gamma}=6.6 \mathrm{~Hz}\right) ;{ }^{13} \mathrm{C} \mathrm{NMR}\left(75 \mathrm{MHz}, \mathrm{CDCl}_{3}\right) \delta 170.2$ (CO Val), 147.3 (C2 oNbs), 138.7 (C3 2iodophenyl), 133.3 (C1 oNbs), 133.1, 133.6 (C6 2-iodophenyl, C3 oNbs), 131.5, 131.6 (C4, C5 oNbs), 129.0 (C1 2-iodophenyl), 127.7, 129.7, (C4, C5 2-iodophenyl), 124.0 (C6 oNbs), 100.3 (C2 2-iodophenyl), 88.4 (C2 propargyl), 86.1 (C3 propargyl), 65.5 ( $\alpha$ Val), $61.1\left(\mathrm{CH}_{2}\right.$ OEt), 35.5 (C1 propargyl), 19.5, 20.2 ( $\left.\gamma \gamma^{\prime} \mathrm{Val}\right), 29.0$ ( $\beta$ Val), $14.0\left(\mathrm{CH}_{3} \mathrm{OEt}\right)$; HRMS (MALDI) $m / z[\mathrm{M}+\mathrm{Na}]^{+}$calcd for $\mathrm{C}_{22} \mathrm{H}_{23} \mathrm{IN}_{2} \mathrm{O}_{6} \mathrm{SNa}$, 593.0214; found, 593.0228.

\section{(oNbs)[3-(2-Iodophenyl)propargyl]-l-leucine ethyl ester (2c):}

Yield $860 \mathrm{mg}$ (49\%) (yellow oil); $R_{f} 0.69$ (petrol ether/EtOAc 2:1); [ $\left.\alpha_{\mathrm{D}}\right]-35.0$ (c 1.0, EtOAc); ${ }^{1} \mathrm{H}$ NMR (600 MHz, $\left.\mathrm{CDCl}_{3}\right) \delta 8.20-8.19(\mathrm{~m}, 1 \mathrm{H}, \mathrm{H} 3 \mathrm{oNbs}), 7.81-7.80(\mathrm{~m}, 1 \mathrm{H}, \mathrm{H} 6$ oNbs), 7.65-7.60 (m, 3H, H3 2-iodophenyl; H4, H5 oNbs), 7.35-7.26 (m, 2H, H5, H6 2iodophenyl), 7.01-6.98 (m, 1H, H4, 2-iodophenyl), 4.76-4.74 (m, 1H, $\alpha$ Leu), 4.50, 4.65 (d, $2 \mathrm{H}, \mathrm{CH}_{2}$ propargyl, $\left.{ }^{2} J_{\mathrm{HH}}=19.0 \mathrm{~Hz}\right), 4.03\left(\mathrm{q}, 2 \mathrm{H}, \mathrm{CH}_{2} \mathrm{OEt},{ }^{3} J_{\mathrm{HH}}=7.0 \mathrm{~Hz}\right), 1.84,2.01(\mathrm{~m}$, $\left.2 \mathrm{H}, \beta \beta^{\prime} \mathrm{Leu}\right), 1.95(\mathrm{~m}, 1 \mathrm{H}, \gamma \mathrm{Leu}), 1.12\left(\mathrm{t}, 3 \mathrm{H}, \mathrm{CH}_{3} \mathrm{OEt},{ }^{3} J_{\mathrm{HH}}=7.0 \mathrm{~Hz}\right), 0.95,0.99(\mathrm{~d}, 6 \mathrm{H}$, $\left.\delta \delta^{\prime} \mathrm{Leu},{ }^{3} J_{\gamma \delta}=6.7 \mathrm{~Hz}\right) ;{ }^{13} \mathrm{C} \mathrm{NMR}\left(150 \mathrm{MHz}, \mathrm{CDCl}_{3}\right) \delta 170.7$ (CO Leu), $147.6(\mathrm{C} 2 \mathrm{oNbs})$, 138.2 (C3 2-iodophenyl), 132.8 (C1 oNbs), 132.5, 133.0 (C6 2-iodophenyl, C3 oNbs), 130.8, 131.1 (C4, C5 oNbs), 128.5 (C1 2-iodophenyl), 127.2, 129.2 (C4, C5 2-iodophenyl), 123.7 (C6 oNbs), 99.9 (C2 2-iodophenyl), 87.9 (C2 propargyl), 85.6 (C3 propargyl), $60.9\left(\mathrm{CH}_{2}\right.$ OEt), $58.1(\alpha$ Leu), 38.6 ( $\beta$ Leu $), 35.2\left(\right.$ C1 propargyl), $24.2(\gamma$ Leu $), 21.0,22.3\left(\delta \delta^{\prime}\right.$ Leu $), 13.5$ $\left(\mathrm{CH}_{3} \mathrm{OEt} \text { ); HRMS (MALDI) } \mathrm{m} / z \text { [M }+\mathrm{Na}\right]^{+}$calcd for $\mathrm{C}_{23} \mathrm{H}_{25} \mathrm{IN}_{2} \mathrm{O}_{6} \mathrm{SNa}, 607.0370$; found, 607.0366 .

\section{General Procedure for the Synthesis of 3}

$2(1 \mathrm{mmol})$, piperidine $(1 \mathrm{mmol}), \mathrm{CuI}(0.1 \mathrm{mmol})$, and $\mathrm{Pd}\left(\mathrm{PPh}_{3}\right)_{4}(0.01 \mathrm{mmol})$ are mixed in THF under argon at room temperature for $30 \mathrm{~min} .1(1 \mathrm{mmol})$ and piperidine $(1 \mathrm{mmol})$ are mixed in THF under argon and added dropwise to the initial solution. The solution is stirred overnight. Solvent is evaporated and the product extracted with EtOAc, washed with brine and water, and purified by flash column chromatography. Symmetric compounds $\mathbf{3 a}-\mathbf{c}$ can be prepared alternatively: 1,2 -diiodobenzene $(0.5 \mathrm{mmol})$, piperidine $(1 \mathrm{mmol}), \mathrm{CuI}(0.1 \mathrm{mmol})$, and $\mathrm{Pd}\left(\mathrm{PPh}_{3}\right)_{4}(0.01 \mathrm{mmol})$ are mixed in THF under argon at room temperature for $30 \mathrm{~min} . \mathbf{1}$ $(1 \mathrm{mmol})$ and piperidine (1 mmol) are mixed in THF under argon and added dropwise to the initial solution. The solution is stirred until all substrate is consumed, approximately $2 \mathrm{~h}$. Solvent is evaporated and the product extracted with EtOAc, washed with brine and water, and purified by flash column chromatography. 
Gredičak M; Matanović I; Zimmermann B \& Jerić I. "Bergman Cyclization of Acyclic Amino Acid Derived Enediynes Leads to the Formation of 2,3-Dihydrobenzo[f]isoindoles", Journal of Organic Chemistry, Vol.75, No.18, pp. 6219-6228. DOI: 10.1021/jo101302n

\section{3,3'-(1,2-Phenylene)bis(prop-2-yne-1-yl)bis[(2-nitrobenzensulfonyl)-l-alanine ethyl ester] (3a):}

Yield $377 \mathrm{mg}\left(50 \%\right.$ ) (yellow oil); $R_{f} 0.37$ (petrol ether/EtOAc 2:1); [ $\left.\alpha_{\mathrm{D}}\right]-57.0$ (c 1.0, $\mathrm{MeOH}) ;{ }^{1} \mathrm{H}$ NMR $\left(300 \mathrm{MHz}, \mathrm{CDCl}_{3}\right) \delta 8.23-8.20(\mathrm{~m}, 2 \mathrm{H}, \mathrm{H} 3 \mathrm{oNbs}), 7.64-7.58(\mathrm{~m}, 6 \mathrm{H}$, $\mathrm{H} 4,5,6$ oNbs), 7.29-7.20 (m, 4H, H3,6, H4,5 phenylene), 4.86 (q, 2H, $\alpha$ Ala, ${ }^{3} J_{\alpha \beta}=7.2 \mathrm{~Hz}$ ), 4.38, $4.46\left(\mathrm{~d}, 4 \mathrm{H}, \mathrm{CH}_{2}\right.$ propyniyl, $\left.{ }^{2} J_{\mathrm{HH}}=19.0 \mathrm{~Hz}\right), 4.08\left(\mathrm{q}, 4 \mathrm{H}, \mathrm{CH}_{2} \mathrm{OEt},{ }^{3} J_{\mathrm{HH}}=7.2 \mathrm{~Hz}\right)$, $1.70\left(\mathrm{~d}, 6 \mathrm{H}, \beta \mathrm{Ala},{ }^{3} J_{\alpha \beta}=7.2 \mathrm{~Hz}\right), 1.15\left(\mathrm{t}, 6 \mathrm{H}, \mathrm{CH}_{3} \mathrm{OEt},{ }^{3} J_{\mathrm{HH}}=7.2 \mathrm{~Hz}\right) ;{ }^{13} \mathrm{C}$ NMR $(75 \mathrm{MHz}$, $\left.\mathrm{CDCl}_{3}\right) \delta 171.1$ (CO Ala), 147.9 (C2 oNbs), 133.7 (C1 oNbs), 133.5 (C5 oNbs), 131.4, 131.8, 132.0 (C3, C4 oNbs; C3,6 phenylene), 128.2 (C4,5 phenylene), 124.8 (C1,2 phenylene), 124.2 (C6 oNbs), 88.5 (C22' propynyl), 83.0 (C33' propynyl), $61.6\left(\mathrm{CH}_{2} \mathrm{OEt}\right), 55.9$ ( $\left.\alpha \mathrm{Ala}\right)$, 35.7 (C11' propynyl), 16.7 ( $\beta$ Ala), $13.9\left(\mathrm{CH}_{3} \mathrm{OEt}\right.$ ); HRMS (MALDI) $\mathrm{m} / z[\mathrm{M}+\mathrm{Na}]^{+}$calcd for $\mathrm{C}_{34} \mathrm{H}_{34} \mathrm{NaN}_{4} \mathrm{O}_{12} \mathrm{~S}_{2}, 777.1506$; found, 777.1471.

\section{3,3'-(1,2-Phenylene)bis(prop-2-yne-1-yl)bis[(2-nitrobenzensulfonyl)-l-valine ethyl ester]} (3b):

Yield $390 \mathrm{mg}$ (48\%) (yellow oil); $R_{f} 0.69$ (petrol ether/EtOAc 1:1); $\left[\alpha_{\mathrm{D}}\right]-67.0$ (c 1.0, $\mathrm{MeOH}) ;{ }^{1} \mathrm{H}$ NMR $\left(300 \mathrm{MHz}, \mathrm{CDCl}_{3}\right) \delta 8.24-8.20(\mathrm{~m}, 2 \mathrm{H}, \mathrm{H} 3 \mathrm{oNbs}), 7.64-7.58(\mathrm{~m}, 6 \mathrm{H}$, H4,5,6 oNbs), 7.29-7.21 (m, 4H, H3,6, H4,5 phenylene), 4.56-4.74 (m, 2H, $\alpha$ Val), 4.25 (d, $4 \mathrm{H}, \mathrm{CH}_{2}$ propynyl, $\left.{ }^{2} J_{\mathrm{HH}}=19.0 \mathrm{~Hz}\right), 4.09-3.96(\mathrm{~m}, 2 \mathrm{H}, \beta \mathrm{Val}), 4.02\left(\mathrm{q}, 4 \mathrm{H}, \mathrm{CH}_{2} \mathrm{OEt},{ }^{3} J_{\mathrm{HH}}=\right.$ $7.1 \mathrm{~Hz}), 1.09\left(\mathrm{t}, 6 \mathrm{H}, \mathrm{CH}_{3} \mathrm{OEt},{ }^{3} J_{\mathrm{HH}}=7.1 \mathrm{~Hz}\right), 1.03,1.14\left(\mathrm{~d}, 12 \mathrm{H}, \gamma \gamma^{\prime} \mathrm{Val},{ }^{3} J_{\beta \gamma}=6.7 \mathrm{~Hz}\right) ;{ }^{13} \mathrm{C}$ NMR (150 MHz, $\left.\mathrm{CDCl}_{3}\right) \delta 170.1$ (CO Val), 148.2 (C2 oNbs), 133.6 (C5 oNbs), 133.2 (C1 oNbs), $13.9\left(\mathrm{CH}_{3} \mathrm{OEt}\right), 131.5,131.6,132.0,(\mathrm{C} 3, \mathrm{C} 4 \mathrm{oNbs}$; $\mathrm{C} 3,6$ phenylene), 128.1 (C4,5 phenylene), 125.0 ( $\mathrm{C} 1,2$ phenylene), 123.9 (C6 oNbs), 88.8 (C22' propynyl), 82.7 (C33' propynyl), $65.6(\alpha \mathrm{Val}), 61.1\left(\mathrm{CH}_{2} \mathrm{OEt}\right), 35.7$ (C11' propynyl), 28.9 ( $\beta$ Val $), 19.5,19.9\left(\gamma \gamma^{\prime}\right.$ Val); HRMS (MALDI) $\mathrm{m} / z[\mathrm{M}+\mathrm{Na}]^{+}$calcd for $\mathrm{C}_{38} \mathrm{H}_{42} \mathrm{NaN}_{4} \mathrm{O}_{12} \mathrm{~S}_{2}, 833.2132$; found, 833.2158.

\section{3,3'-(1,2-Phenylene)bis(prop-2-yne-1-yl)bis[(2-nitrobenzensulfonyl)-l-leucine ethyl ester]} (3c):

Yield $394 \mathrm{mg}$ (47\%) (yellow oil); $R_{f} 0.68$ (petrol ether/EtOAc 1:1); $\left[\alpha_{\mathrm{D}}\right]-16.0$ (c 1.0, $\mathrm{MeOH}) ;{ }^{1} \mathrm{H}$ NMR (300 MHz, DMSO- $\left.d_{6}\right) \delta 8.23-8.11$ (m, 2H, H3 oNbs), 7.75-7.63 (m, 6H, $\mathrm{H} 4,5,6$ oNbs), 7.47-7.35 (m, 4H, H3,6, H4,5 phenylene), 4.78-4.67 (m, 2H, $\alpha$ Leu), 4.36, $4.20\left(\mathrm{~d}, 4 \mathrm{H}, \mathrm{CH}_{2}\right.$ propynyl, $\left.{ }^{2} J_{\mathrm{HH}}=19.0 \mathrm{~Hz}\right), 4.03\left(\mathrm{q}, 4 \mathrm{H}, \mathrm{CH}_{2} \mathrm{OEt},{ }^{3} J_{\mathrm{HH}}=7.2 \mathrm{~Hz}\right), 2.06-1.71$ $\left(\mathrm{m}, 6 \mathrm{H}, \gamma\right.$ Leu, $\left.\beta \beta^{\prime} \mathrm{Leu}\right), 1.13\left(\mathrm{t}, 6 \mathrm{H}, \mathrm{CH}_{3} \mathrm{OEt},{ }^{3} J_{\mathrm{HH}}=7.2 \mathrm{~Hz}\right), 0.83,0.90\left(\mathrm{~d}, 12 \mathrm{H}, \delta \delta^{\prime}\right.$ Leu, $\left.{ }^{3} J_{\mathrm{HH}}=6.5 \mathrm{~Hz}\right) ;{ }^{13} \mathrm{C} \mathrm{NMR}\left(75 \mathrm{MHz}, \mathrm{DMSO}-d_{6}\right) \delta 171.3$ (CO Leu), 147.4 (C2 oNbs), 134.8 (C5 oNbs), 131.2 (C1 oNbs), 130.7, 131.5, 132.2 (C3, C4 oNbs; C3,6 phenylene), 128.8 (C4,5 phenylene), 124.5 (C1,2 phenylene), 124.0 (C6 oNbs), 89.8 (C22' propynyl), 81.3 $\left(\mathrm{C} 33^{\prime}\right.$ propynyl), $60.9\left(\mathrm{CH}_{2} \mathrm{OEt}\right), 58.3(\alpha \mathrm{Leu}), 38.0$ ( $\left.\beta \mathrm{Leu}\right), 35.6\left(\mathrm{C} 11^{\prime}\right.$ propynyl), $23.9(\gamma$ Leu), 21.6, $22.6\left(\delta \delta^{\prime} \mathrm{Leu}\right), 13.4\left(\mathrm{CH}_{3} \mathrm{OEt}\right)$; HRMS (MALDI) $\mathrm{m} / \mathrm{z}[\mathrm{M}+\mathrm{Na}]^{+}$calcd for $\mathrm{C}_{40} \mathrm{H}_{46} \mathrm{NaN}_{4} \mathrm{O}_{12} \mathrm{~S}_{2}, 861.2451$; found, 861.2411. 
Gredičak M; Matanović I; Zimmermann B \& Jerić I. "Bergman Cyclization of Acyclic Amino Acid Derived Enediynes Leads to the Formation of 2,3-Dihydrobenzo[f]isoindoles", Journal of Organic Chemistry, Vol.75, No.18, pp. 6219-6228. DOI: 10.1021/jo101302n

(2-Nitrobenzensulfonyl)[3-(2-(3-(N-((S)-1-ethoxy-1-oxopropan-2-yl)-2nitrophenylsulfonamido)prop-1-ynyl)phenyl)prop-2-ynyl]-l-valine ethyl ester (3d): Yield $400 \mathrm{mg}\left(51 \%\right.$ ) (yellow oil); $R_{f} 0.36$ (petrol ether/EtOAc 2:1); [ $\left.\alpha_{\mathrm{D}}\right]-47.0$ (c 1.0, $\mathrm{MeOH}) ;{ }^{1} \mathrm{H}$ NMR $\left(600 \mathrm{MHz}, \mathrm{CDCl}_{3}\right) \delta 8.26-8.18$ (m, 2H, H3 oNbs Ala,Val), 7.65-7.59 (m, $6 \mathrm{H}, \mathrm{H} 4,5,6$ oNbs Ala,Val), 7.27-7.25 (m, 2H, H3,6 phenyl), 7.22-7.20 (m, 2H, H4,5 phenyl), $4.86\left(\mathrm{q}, 1 \mathrm{H}, \alpha\right.$ Ala, $\left.{ }^{3} J_{\alpha \beta}=6.9 \mathrm{~Hz}\right), 4.71-4.57,4.41-4.37$ (m, 4H, $\mathrm{CH}_{2}$ prop-2-ynyl, $\mathrm{CH}_{2}$ prop-1-ynyl), 4.22 (d, 1H, $\alpha$ Val, $\left.{ }^{3} J_{, \beta}=10.0 \mathrm{~Hz}\right), 4.11-3.96\left(\mathrm{~m}, 4 \mathrm{H}, \mathrm{CH}_{2} \mathrm{OEt}\right.$, Ala, Val), 2.44-2.37 (m, 1H, $\beta$ Val), $1.71\left(\mathrm{~d}, 3 \mathrm{H}, \beta\right.$ Ala,$\left.{ }^{3} J_{\alpha \beta}=6.9 \mathrm{~Hz}\right), 1.17-1.02\left(\mathrm{~m}, 12 \mathrm{H}, \mathrm{CH}_{3} \mathrm{OEt}\right.$ Ala, Val, $\gamma \gamma^{\prime}$ Val); ${ }^{13} \mathrm{C}$ NMR (150 MHz, $\left.\mathrm{CDCl}_{3}\right) \delta 169.5,170.7$ (CO Ala,Val), 147.4, 147.7 (C2 oNbs Ala,Val), 132.9, 133.3 (C1 oNbs Ala,Val), 132.7, 133.1 (C5 oNbs Ala,Val), 131.0, 131.1, 131.3, 131.4, 131.5, 131.6 (C3,4 oNbs Ala,Val, C3,6 phenyl), 127.6, 127.7 (C4,5 phenyl), 124.3, 124.5 (C1,2 phenyl), 123.4, 123.6 (C6 oNbs Ala,Val), 88.0, 88.3 (C2 prop-2ynyl, C2 prop-1-ynyl), 82.1, 82.6 (C3 prop-2-ynyl, C1 prop-1-ynyl), 65.1 ( $\alpha$ Val), 60.6, 61.1 $\left(\mathrm{CH}_{2} \mathrm{OEt} \mathrm{Ala}, \mathrm{Val}\right), 55.5$ ( $\left.\alpha \mathrm{Ala}\right), 35.1,35.2$ (C1 prop-2-ynyl, $\mathrm{C} 3$ prop-1-ynyl), 28.4 ( $\beta$ Val), 18.9, 19.4 ( $\gamma \gamma^{\prime}$ Val), 16.0 ( $\beta$ Ala), 13.4, $13.5\left(\mathrm{CH}_{3}\right.$ OEt Ala,Val); HRMS (MALDI) $\mathrm{m} / z$ [M + $\mathrm{Na}]^{+}$calcd for $\mathrm{C}_{36} \mathrm{H}_{38} \mathrm{~N}_{4} \mathrm{O}_{12} \mathrm{~S}_{2} \mathrm{Na}$, 805.1819; found, 805.1840.

(2-Nitrobenzensulfonyl)[3-(2-(3-(N-(2-ethoxy-2-oxoethyl)-2nitrophenylsulfonamido)prop-1-ynyl)phenyl)prop-2-ynyl]-l-valine ethyl ester (3e):

Yield $453 \mathrm{mg}$ (59\%) (yellow oil); $R_{f} 0.60$ (petrol ether/EtOAc 1:1); [ $\left.\alpha_{\mathrm{D}}\right]-10(c 0.5, \mathrm{MeOH})$; ${ }^{1} \mathrm{H}$ NMR $\left(300 \mathrm{MHz}, \mathrm{CDCl}_{3}\right) \delta 8.23-8.14(\mathrm{~m}, 2 \mathrm{H}, \mathrm{H} 3$ oNbs Val,Gly), 7.67-7.58 (m, 6H, $\mathrm{H} 4,5,6$ oNbs Val,Gly), 7.25-7.21 (m, 4H, H3,4,5,6 phenyl), 4.61, 4.64 (s, 4H, $\mathrm{CH}_{2}$ prop-2ynyl, $\mathrm{CH}_{2}$ prop-1-ynyl), 4.41 (s, 2H, $\alpha$ Gly), 4.26-4.10 (m, 4H, $\mathrm{CH}_{2}$ OEt Val,Gly), 4.08-3.94 (m, 1H, $\alpha$ Val), 2.45-2.34 (m, 1H, $\beta$ Val), 1.26-1.01 (m, 12H, $\mathrm{CH}_{3}$ OEt Val,Gly, $\gamma \gamma^{\prime}$ Val); ${ }^{13} \mathrm{C} \mathrm{NMR}\left(75 \mathrm{MHz}, \mathrm{CDCl}_{3}\right) \delta 170.0,168.5$ (CO Val,Gly), 148.0, 148.2 (C2 oNbs Val,Gly), 133.6, 133.7 (C5 oNbs Val,Gly), 133.1, 133.2 (C1 oNbs Val,Gly), 128.0, 128.2, 128.3, 131.1, 131.5, 131.6, 131.9, 132.0 (C4,5, C3,6 phenyl, C3,4 oNbs Val,Gly), 124.5, 125.0 (C1,2 phenyl), 123.9, 124.2 (C6 oNbs Val,Gly), 88.8, 88.9 (C2 prop-2-ynyl, C2 prop-1-ynyl), 82.6, 84.4 (C3 prop-2-ynyl, C1 prop-1-ynyl), 65.5 ( $\alpha$ Val), 61.1, $61.6\left(\mathrm{CH}_{2} \mathrm{OEt}\right.$ Val,Gly), 47.7 ( $\alpha$ Gly), 35.6, 35.7 (C1 prop-2-ynyl, C3 prop-1-ynyl), 28.9 ( $\beta$ Val), 19.4, 19.8 ( $\gamma \gamma^{\prime}$ Val), 13.9, $14.0\left(\mathrm{CH}_{3}\right.$ OEt Val,Gly); HRMS (MALDI) $\mathrm{m} / z[\mathrm{M}+\mathrm{Na}]^{+}$calcd for $\mathrm{C}_{35} \mathrm{H}_{36} \mathrm{~N}_{4} \mathrm{O}_{12} \mathrm{~S}_{2} \mathrm{Na}$, 791.1663; found, 791.1673.

\section{General Procedure for the Synthesis of 4}

Enediyne $3(0.5 \mathrm{mmol}), \mathrm{K}_{2} \mathrm{CO}_{3}(1 \mathrm{mmol})$, and $\mathrm{PhSH}(1 \mathrm{mmol})$ are mixed in DMF at room temperature for $1 \mathrm{~h}$. Solvent is evaporated and the product extracted with EtOAc, washed with brine and water, and purified by flash column chromatography.

3,3'-(1,2-Phenylene)bis(prop-2-yne-1-yl)bis[l-alanine ethyl ester] (4a):

Yield $144 \mathrm{mg}$ (75\%) (yellow oil); $R_{f} 0.42$ (EtOAc); $\left[\alpha_{\mathrm{D}}\right]-29.0$ (c 1.0, EtOAc); ${ }^{1} \mathrm{H}$ NMR (300 $\left.\mathrm{MHz}, \mathrm{CD}_{3} \mathrm{OD}\right) \delta$ 7.43-7.39 (m, 2H, H3,6 phenylene), 7.29-7.27 (m, 2H, H4,5 phenylene), 4.19 (q, 4H, $\mathrm{CH}_{2} \mathrm{OEt},{ }^{3} \mathrm{~J}_{\mathrm{HH}}=7.0 \mathrm{~Hz}$ ), 3.71 (br s, $6 \mathrm{H}, \alpha$ Ala, $\mathrm{CH}_{2}$ propynyl), 1.35 (d, $6 \mathrm{H}, \beta$ $\left.\mathrm{Ala},{ }^{3} J_{\alpha \beta}=6.7 \mathrm{~Hz}\right), 1.26\left(\mathrm{t}, 6 \mathrm{H}, \mathrm{CH}_{3} \mathrm{OEt},{ }^{3} J_{\mathrm{HH}}=7.0 \mathrm{~Hz}\right) ;{ }^{13} \mathrm{C} \mathrm{NMR}\left(75 \mathrm{MHz}, \mathrm{CD}_{3} \mathrm{OD}\right) \delta$ 176.0 (CO Ala), 133.1 (C3,6 phenylene), 129.2 (C4,5 phenylene), 126.7 (C1,2 phenylene), 91.2 (C22' propynyl), 83.7 (C11' propynyl), 62.1 $\left(\mathrm{CH}_{2} \mathrm{OEt}\right), 56.0(\alpha \mathrm{Ala}), 37.6$ (C33' propynyl), 18.5 ( $\beta$ Ala), $14.5\left(\mathrm{CH}_{3} \mathrm{OEt}\right)$; IR (KBr, $\left.25^{\circ} \mathrm{C}\right) 3332,2230,1732,1481,1445$, 1194, 1149, 1068, 1022, 760; HRMS (MALDI) $\mathrm{m} / \mathrm{z}[\mathrm{M}+\mathrm{H}]^{+}$calcd for $\mathrm{C}_{22} \mathrm{H}_{28} \mathrm{~N}_{2} \mathrm{O}_{4}$, 385.2122; found, 385.2117. 
Gredičak M; Matanović I; Zimmermann B \& Jerić I. "Bergman Cyclization of Acyclic Amino Acid Derived Enediynes Leads to the Formation of 2,3-Dihydrobenzo[ $f$ ]isoindoles", Journal of Organic Chemistry, Vol.75, No.18, pp. 6219-6228. DOI: 10.1021/jo101302n

3,3'-(1,2-Phenylene)bis(prop-2-yne-1-yl)bis[l-valine ethyl ester] (4b):

Yield $147 \mathrm{mg}(67 \%)$ (yellow oil); $R_{f} 0.49$ (EtOAc/EtOH 10:1); $\left[\alpha_{\mathrm{D}}\right]-10.0(c 0.5, \mathrm{MeOH}) ;{ }^{1} \mathrm{H}$

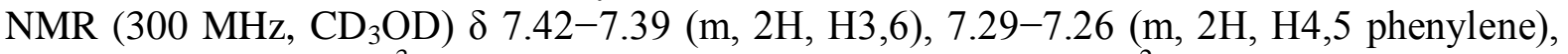
$4.17\left(\mathrm{q}, 4 \mathrm{H}, \mathrm{CH}_{2} \mathrm{OEt},{ }^{3} J_{\mathrm{HH}}=7.1 \mathrm{~Hz}\right), 3.67\left(\mathrm{~d}, 4 \mathrm{H}, \mathrm{CH}_{2}\right.$ propynyl, $\left.{ }^{2} J_{\mathrm{HH}}=16.9 \mathrm{~Hz}\right), 3.36(\mathrm{~d}$, $\left.2 \mathrm{H}, \alpha \mathrm{Val},{ }^{3} J_{\alpha \beta}=5.6 \mathrm{~Hz}\right), 2.07-1.96(\mathrm{~m}, 2 \mathrm{H}, \beta \mathrm{Val}), 2.00(\mathrm{~m}, 2 \mathrm{H}, \beta \mathrm{Val}), 1.23\left(\mathrm{t}, 6 \mathrm{H}, \mathrm{CH}_{3}\right.$ $\left.\mathrm{OEt},{ }^{3} J_{\mathrm{HH}}=7.1 \mathrm{~Hz}\right), 0.97,0.99\left(\mathrm{~d}, 12 \mathrm{H}, \gamma \gamma^{\prime} \mathrm{Val},{ }^{3} J_{\beta \gamma}=2.4 \mathrm{~Hz}\right) ;{ }^{13} \mathrm{C}$ NMR $\left(75 \mathrm{MHz}, \mathrm{CD}_{3} \mathrm{OD}\right)$ : $\delta$ 174.2 (CO Val), 131.7 (C3,6 phenylene), 127.6 (C4,5 phenylene), 125.4 (C1,2 phenylene), 90.4 (C22' propynyl), 82.1 (C11' propynyl), 65.6 ( $\alpha$ Val), $60.4\left(\mathrm{CH}_{2} \mathrm{OEt}\right), 37.4$ (C33' propynyl), 31.4 ( $\beta$ Val), 17.6, 17.9 ( $\gamma \gamma^{\prime}$ Val $), 13.2\left(\mathrm{CH}_{3} \mathrm{OEt}\right)$; IR $\left(\mathrm{KBr}, 25{ }^{\circ} \mathrm{C}\right) 3330,2228$, $1730,1479,1467,1439,1186,1148,1024,756$; HRMS (MALDI) $\mathrm{m} / z . \mathrm{M}+\mathrm{H}]^{+}$calcd for $\mathrm{C}_{26} \mathrm{H}_{36} \mathrm{~N}_{2} \mathrm{O}_{4}, 441.2747$; found, 441.2739.

\section{3,3'-(1,2-Phenylene)bis(prop-2-yne-1-yl)bis[l-leucine ethyl ester] (4c):}

Yield $166 \mathrm{mg}(71 \%)$ (yellow oil); $R_{f} 0.36$ (toluene/EtOAc 1:1); $\left[\alpha_{\mathrm{D}}\right]-4.5(c 0.5, \mathrm{MeOH}) ;{ }^{1} \mathrm{H}$ NMR (300 MHz, CD 3 OD) $\delta 7.42-7.24\left(\mathrm{~m}, 4 \mathrm{H}, \mathrm{H} 3,6, \mathrm{H} 4,5\right.$ phenylene), 4.16 (q, 4H, $\mathrm{CH}_{2}$ OEt, $\left.{ }^{3} J_{\mathrm{HH}}=7.2 \mathrm{~Hz}\right), 3.99\left(\mathrm{~s}, \mathrm{CH}_{2}\right.$, propynyl), 3.62 (br d, $\left.2 \mathrm{H}, \alpha \mathrm{Leu}\right), 1.80-1.69(\mathrm{~m}, 2 \mathrm{H}, \gamma$ Leu), $1.54(\mathrm{~m}, 4 \mathrm{H}, \beta \mathrm{Leu}), 1.25\left(\mathrm{t}, 6 \mathrm{H}, \mathrm{CH}_{3} \mathrm{OEt},{ }^{3} J_{\mathrm{HH}}=7.2 \mathrm{~Hz}\right), 0.95\left(\mathrm{~d}, 12 \mathrm{H}, \delta \delta^{\prime} \mathrm{Leu},{ }^{3} J_{\gamma \delta}=\right.$ $4.6 \mathrm{~Hz}) ;{ }^{13} \mathrm{C}$ NMR (75 MHz, $\left.\mathrm{CD}_{3} \mathrm{OD}\right) \delta 174.8$ (CO Leu), 131.5, (C3,6 phenylene), 127.7 (C4,5 phenylene), 125.4 (C1,2 phenylene), 89.2 (C22' propynyl), 81.5 (C11' propynyl), 60.6 $\left(\mathrm{CH}_{2} \mathrm{OEt}\right), 59.1$ ( $\left.\alpha \mathrm{Leu}\right), 42.0(\beta \mathrm{Leu}), 36.7$ (C33' propynyl), $24.6(\gamma \mathrm{Leu}), 21.4,21.6\left(\delta \delta^{\prime}\right.$ Leu), 13.2 ( $\left.\mathrm{CH}_{3} \mathrm{OEt}\right)$; IR (KBr, $\left.25^{\circ} \mathrm{C}\right)$ 3336, 2233, 1732, 1481, 1466, 1445, 1194, 1148, 1026, 762; HRMS (MALDI) $m / z[\mathrm{M}+\mathrm{Na}]^{+}$calcd for $\mathrm{C}_{28} \mathrm{H}_{40} \mathrm{~N}_{2} \mathrm{O}_{4} \mathrm{Na}$, 491.2880; found, 491.2897.

[3-(2-(3-((S)-1-Ethoxy-1-oxopropan-2-ylamino)prop-1-ynyl)phenyl)prop-2-ynyl]-1-valine ethyl ester (4d):

Yield $140 \mathrm{mg}(68 \%)$ (yellow oil); $R_{f} 0.34$ (petrol ether/EtOAc 1:1); $\left[\alpha_{\mathrm{D}}\right]-22(c 0.5 \mathrm{MeOH})$; ${ }^{1} \mathrm{H}$ NMR $\left(600 \mathrm{MHz}, \mathrm{CDCl}_{3}\right) \delta$ 7.41-7.39 (m, 2H, H4,5 phenyl), 7.23-7.21 (m, 2H, H3,6 phenyl), 4.22-4.13 (m, 4H, $\mathrm{CH}_{2}$ OEt Ala,Val), 3.76-3.63 (m, 5H, $\mathrm{CH}_{2}$ prop-2-ynyl, $\mathrm{CH}_{2}$ prop-1-ynyl, $\alpha$ Ala), 3.27 (d, $1 \mathrm{H}, \alpha$ Val, $\left.{ }^{3} J_{\alpha \beta}=5.42 \mathrm{~Hz}\right), 2.03-1.97(\mathrm{~m}, 1 \mathrm{H}, \beta \mathrm{Val}), 1.36(\mathrm{~d}$, $3 \mathrm{H}, \beta$ Ala, $\left.{ }^{3} J_{\alpha \beta}=7.12 \mathrm{~Hz}\right), 1.25,1.27\left(\mathrm{t}, 6 \mathrm{H}, \mathrm{CH}_{3} \mathrm{OEt}\right.$ Ala, Val, $\left.{ }^{3} J_{\mathrm{HH}}=7.02 \mathrm{~Hz}\right), 0.96,0.99$ $\left(\mathrm{d}, 6 \mathrm{H}, \gamma \gamma^{\prime} \mathrm{Val},{ }^{3} J_{\beta \gamma}=6.75 \mathrm{~Hz}\right) ;{ }^{13} \mathrm{C} \mathrm{NMR}\left(150 \mathrm{MHz}, \mathrm{CDCl}_{3}\right) \delta 174.8,175.2$ (CO Ala,Val), 132.2, 132.3 (C3,6 phenyl), 127.9, 128.0 (C4,5 phenyl), 125.6, 125.8 (C1,2 phenyl), 90.9, 91.4 (C2 prop-2-ynyl, C2 prop-1-ynyl), 82.4, 82.7 (C13' prop-2-ynyl, C1 prop-1-ynyl), 66.2 $(\alpha \mathrm{Val}), 60.8,61.1\left(\mathrm{CH}_{2}\right.$ OEt Ala,Val), 55.2 ( $\alpha$ Ala), 37.6, 37.8 (C1 prop-2-ynyl, C3 prop-1ynyl), 31.9 ( $\beta$ Val), 18.7, 19.2 ( $\gamma \gamma^{\prime}$ Val $), 18.4$ ( $\beta$ Ala $), 14.4,14.5\left(\mathrm{CH}_{3}\right.$ OEt Ala, Val); IR (KBr, $25^{\circ} \mathrm{C}$ ) 3337, 2232, 1730, 1481, 1466, 1445, 1188, 1148, 1026, 760; HRMS (MALDI) m/z [M $+\mathrm{Na}]^{+}$calcd for $\mathrm{C}_{24} \mathrm{H}_{32} \mathrm{~N}_{2} \mathrm{O}_{4} \mathrm{Na}, 435.2254$; found, 435.2251 . 
Gredičak M; Matanović I; Zimmermann B \& Jerić I. "Bergman Cyclization of Acyclic Amino Acid Derived Enediynes Leads to the Formation of 2,3-Dihydrobenzo[f]isoindoles", Journal of Organic Chemistry, Vol.75, No.18, pp. 6219-6228. DOI: 10.1021/jo101302n

\section{[3-(2-(3-(2-Ethoxy-2-oxoethylamino)prop-1-ynyl)pheny)prop-2-ynyl]-l-valine ethyl ester} (4e):

Yield $133 \mathrm{mg}(67 \%)$ (yellow oil); $R_{f} 0.52$ (EtOAc/petrol ether 2:1); $\left[\alpha_{\mathrm{D}}\right]-5(c 0.5 \mathrm{MeOH}) ;{ }^{1} \mathrm{H}$ NMR $\left(300 \mathrm{MHz}, \mathrm{CDCl}_{3}\right): \delta 7.43-7.38(\mathrm{~m}, 2 \mathrm{H}, \mathrm{H} 4,5$ phenyl), 7.24-7.21 (m, 2H, H3,6 phenyl), 4.24-4.11 (m, 4H, $\mathrm{CH}_{2}$ OEt Val,Gly), 3.77-3.63 (m, 6H, $\mathrm{CH}_{2}$ prop-2-ynyl, $\mathrm{CH}_{2}$ prop-1-ynyl, $\alpha$ Gly), 3.27 (d, 1H, $\alpha$ Val, $\left.{ }^{3} J_{\alpha \beta}=5.44 \mathrm{~Hz}\right), 2.09-1.97(\mathrm{~m}, 1 \mathrm{H}, \beta$ Val $), 1.25,1.28$ $\left(\mathrm{t}, 6 \mathrm{H}, \mathrm{CH}_{3} \mathrm{OEt}\right.$ Val,Gly, $\left.{ }^{3} J_{\mathrm{HH}}=7.2 \mathrm{~Hz}\right), 0.96,0.99\left(\mathrm{~d}, 6 \mathrm{H}, \gamma \gamma^{\prime}\right.$ Val, $\left.{ }^{3} J_{\beta \gamma}=6.9 \mathrm{~Hz}\right) ;{ }^{13} \mathrm{C} \mathrm{NMR}$ $\left(75 \mathrm{MHz}, \mathrm{CDCl}_{3}\right) \delta$ 172.0, 174.6 (CO Val,Gly), 131.9, 132.1 (C4,5 phenyl), 127.7, 127.8 (C3,6 phenyl), 125.4, 125.6 (C1,2 phenyl), 90.5, 91.2 (C2 prop-2-ynyl, C2 prop-1-ynyl), 82.2, 82.9 (C3 prop-2-ynyl, C1 prop-1-ynyl), 66.0 ( $\alpha$ Val), 60.6, $60.9\left(\mathrm{CH}_{2} \mathrm{OEt}\right.$ Val,Gly), 49.3 ( $\alpha$ Gly), 38.5, 38.6 (C1 prop-2-ynyl, C3 prop-1-ynyl), 18.4, 19.2 ( $\gamma \gamma^{\prime}$ Val), 14.2, 14.3 $\left(\mathrm{CH}_{3}\right.$ OEt Val,Gly); IR (KBr, $\left.25^{\circ} \mathrm{C}\right) 3336,2232,1730,1481,1466,1445,1190,1148,1024$, 760; HRMS (MALDI) $m / z$. [M + H $]^{+}$calcd for $\mathrm{C}_{23} \mathrm{H}_{30} \mathrm{~N}_{2} \mathrm{O}_{4}, 399.2278$; found, 399.2262.

General Procedure for the Synthesis of 6

$4(0.25 \mathrm{mmol})$ was dissolved in DMF in a test tube, and 1,4-cyclohexadiene $(2.5 \mathrm{mmol})$ was added. The reaction mixture was degassed, closed under high vacuum, and placed in a preheated oil bath at $T_{\max }$ determined by FT-IR spectroscopy for selected derivative. The solution was heated until all substrate was consumed (monitoring by TLC and MS), approximately $24 \mathrm{~h}$. Solvent was evaporated and the product purified by HPLC.

\section{(S)-Ethyl-2-(1H-benzo[f]isoindol-2(3H)-yl)propanoate (6a):}

Yield $12 \mathrm{mg}(18 \%) ; R_{f} 0.76($ EtOAc/petrol ether $2: 1) ;{ }^{1} \mathrm{H}$ NMR $\left(600 \mathrm{MHz}, \mathrm{CDCl}_{3}\right) \delta 7.83$ $\left(\mathrm{dd}, 2 \mathrm{H}, \mathrm{H} 3,6,{ }^{3} J_{\mathrm{HH}}=6.1 \mathrm{~Hz},{ }^{4} J_{\mathrm{HH}}=3.4 \mathrm{~Hz}\right), 7.74(\mathrm{br} \mathrm{s}, 2 \mathrm{H}, \mathrm{H} 2,7), 7.51\left(\mathrm{dd}, 2 \mathrm{H}, \mathrm{H} 4,5,{ }^{3} J_{\mathrm{HH}}\right.$ $\left.=6.2 \mathrm{~Hz},{ }^{4} J_{\mathrm{HH}}=3.3 \mathrm{~Hz}\right), 5.05,4.88\left(\mathrm{br} \mathrm{d}, 4 \mathrm{H}, \mathrm{CH}_{2}\right.$ isoindole), $4.49\left(\mathrm{q}, 1 \mathrm{H}, \alpha \mathrm{Ala},{ }^{3} J_{\alpha \beta}=7.1\right.$ $\mathrm{Hz}), 4.24\left(\mathrm{q}, 2 \mathrm{H}, \mathrm{CH}_{2} \mathrm{OEt},{ }^{3} J_{\mathrm{HH}}=7.1 \mathrm{~Hz}\right), 1.71\left(\mathrm{~d}, 3 \mathrm{H}, \beta\right.$ Ala, $\left.{ }^{3} J_{\alpha \beta}=7.1 \mathrm{~Hz}\right), 1.28(\mathrm{t}, 3 \mathrm{H}$, $\left.\mathrm{CH}_{3} \mathrm{OEt},{ }^{3} \mathrm{~J}_{\mathrm{HH}}=7.1 \mathrm{~Hz}\right) ;{ }^{13} \mathrm{C} \mathrm{NMR}\left(150 \mathrm{MHz}, \mathrm{CDCl}_{3}\right) \delta 171.3$ (CO Ala), 138.1 (C1,8), 133.3 (C9, 10), 128.0 (C3,6), 125.5 (C4,5), 120.8 (C2,7), 70.1 ( $\alpha$ Ala), $63.6\left(\mathrm{CH}_{2} \mathrm{OEt}\right), 55.4$ $\left(\mathrm{CH}_{2}\right.$ isoindole), 17.0 ( $\beta$ Ala), $14.3\left(\mathrm{CH}_{3} \mathrm{OEt}\right)$; HRMS (MALDI) $\mathrm{m} / \mathrm{z}[\mathrm{M}+\mathrm{H}]^{+}$calcd for $\mathrm{C}_{17} \mathrm{H}_{19} \mathrm{NO}_{2}, 270.1488$; found, 270.1481 .

\section{(S)-Ethyl-2-(1H-benzo[f]isoindol-2(3H)-yl)-3-methylbutanoate (6b):}

Yield $12.6 \mathrm{mg}(17 \%) ; R_{\mathrm{t}} 14.3 \mathrm{~min}$ (Eurospher $100 \mathrm{RP}$ C-18 column; $150 \times 4.5 \mathrm{~mm}$ i.d.; $5 \mu \mathrm{m}$; flow rate $=0.5 \mathrm{~mL} / \mathrm{min}$; mobile phase $=54 \% \mathrm{MeOH} / 0.1 \% \mathrm{TFA}) ;{ }^{1} \mathrm{H}$ NMR $(600 \mathrm{MHz}$, $\mathrm{CD}_{3} \mathrm{OD}$ ) $\delta 8.12$ (br s, 2H, H2,7), 7.90 (br s, $\left.2 \mathrm{H}, \mathrm{H} 3,6\right), 7.54$ (dd, $2 \mathrm{H}, \mathrm{H} 4,5,{ }^{3} J_{\mathrm{HH}}=6.2 \mathrm{~Hz}$, $\left.{ }^{4} J_{\mathrm{HH}}=3.3 \mathrm{~Hz}\right), 4.87,4.81\left(\mathrm{~m}, 2 \mathrm{H}, \mathrm{CH}_{2}\right.$ isoindole), $4.41\left(\mathrm{~d}, 1 \mathrm{H}, \alpha \mathrm{Val},{ }^{3} J_{\alpha \beta}=5.3 \mathrm{~Hz}\right), 4.20(\mathrm{q}$, $\left.2 \mathrm{H}, \mathrm{CH}_{2} \mathrm{OEt},{ }^{3} J_{\mathrm{HH}}=7.1 \mathrm{~Hz}\right), 2.17(\mathrm{~m}, 1 \mathrm{H}, \beta \mathrm{Val}), 1.27\left(\mathrm{t}, 3 \mathrm{H}, \mathrm{CH}_{3} \mathrm{OEt},{ }^{3} J_{\mathrm{HH}}=7.1 \mathrm{~Hz}\right)$, 0.94, $0.96\left(\mathrm{~d}, 6 \mathrm{H}, \gamma \gamma^{\prime} \mathrm{Val},{ }^{3} J_{\beta \gamma}=7.0 \mathrm{~Hz}\right) ;{ }^{13} \mathrm{C} \mathrm{NMR}\left(150 \mathrm{MHz}, \mathrm{CD}_{3} \mathrm{OD}\right) \delta 172.8$ (CO Val), 135.2 (C9, 10), 129.3 (C3,6), 128.2 (C4,5), 123.1 (C2,7), 73.7 ( $\alpha \mathrm{Val}), 62.4\left(\mathrm{CH}_{2} \mathrm{OEt}\right), 49.0$ $\left(\mathrm{CH}_{2}\right.$ isoindole), 32.0 ( $\beta$ Val), 18.2, $19.6\left(\gamma \gamma^{\prime} \mathrm{Val}\right), 14.6\left(\mathrm{CH}_{3} \mathrm{OEt}\right) ; \mathrm{HRMS}$ (MALDI) $\mathrm{m} / \mathrm{z}$ [M $+\mathrm{H}]^{+}$calcd for $\mathrm{C}_{19} \mathrm{H}_{23} \mathrm{NO}_{2}, 298.1801$; found, 298.1797 . 
Gredičak M; Matanović I; Zimmermann B \& Jerić I. "Bergman Cyclization of Acyclic Amino Acid Derived Enediynes Leads to the Formation of 2,3-Dihydrobenzo[f]isoindoles", Journal of Organic Chemistry, Vol.75, No.18, pp. 6219-6228. DOI: 10.1021/jo101302n

(S)-Ethyl 2-(1H-benzo[f]isoindol-2(3H)-yl)-4-methylpentanoate (6c):

Yield $11.7 \mathrm{mg}(15 \%) ; R_{\mathrm{t}} 17.5 \mathrm{~min}$ (Eurospher $100 \mathrm{RP}$ C-18 column; $150 \times 4.5 \mathrm{~mm}$ i.d.; $5 \mu \mathrm{m}$; flow rate $=0.5 \mathrm{~mL} / \mathrm{min} ;$ mobile phase $=54 \% \mathrm{MeOH} / 0.1 \% \mathrm{TFA}) ;{ }^{1} \mathrm{H}$ NMR $(600 \mathrm{MHz}$, $\left.\mathrm{CD}_{3} \mathrm{OD}\right) \delta 8.06$, (br s, 2H, H2,7), 7.87 (br s, 2H, H2,7), 7.51 (dd, $2 \mathrm{H}, \mathrm{H} 4,5,{ }^{3} J_{\mathrm{HH}}=6.3 \mathrm{~Hz}$, $\left.{ }^{4} J_{\mathrm{HH}}=3.4 \mathrm{~Hz}\right), 4.80,4.75\left(\mathrm{~m}, 2 \mathrm{H}, \mathrm{CH}_{2}\right.$ isoindole $), 4.50(\mathrm{~m}, 1 \mathrm{H}, \alpha \mathrm{Leu}), 4.15\left(\mathrm{q}, 2 \mathrm{H}, \mathrm{CH}_{2}\right.$ $\left.\mathrm{OEt},{ }^{3} J_{\mathrm{HH}}=7.2 \mathrm{~Hz}\right), 1.65(\mathrm{~m}, 1 \mathrm{H}, \gamma \mathrm{Leu}), 1.58(\mathrm{~m}, 2 \mathrm{H}, \beta \mathrm{Leu}), 1.24\left(\mathrm{t}, 3 \mathrm{H}, \mathrm{CH}_{3} \mathrm{OEt},{ }^{3} J_{\mathrm{HH}}=\right.$ $7.2 \mathrm{~Hz}), 0.93,0.90\left(\mathrm{~d}, 6 \mathrm{H},{ }^{3} J_{\gamma \delta}=6.5 \mathrm{~Hz}\right) ;{ }^{13} \mathrm{C} \mathrm{NMR}\left(150 \mathrm{MHz}, \mathrm{CDCl}_{3}\right) \delta 171.7(\mathrm{CO} \mathrm{Leu})$, $129.3(\mathrm{C} 3,6), 128.3(\mathrm{C} 4,5), 123.2,(\mathrm{C} 2,7), 67.0(\alpha$ Leu $), 62.5\left(\mathrm{CH}_{2} \mathrm{OEt}\right), 49.0\left(\mathrm{CH}_{2}\right.$ isoindole), 41.8 ( $\beta$ Leu $), 26.1,(\gamma$ Leu $), 23.3,22.0\left(\delta \delta^{\prime} \mathrm{Leu}\right), 14.6\left(\mathrm{CH}_{3} \mathrm{OEt}\right) ; \mathrm{HRMS}$ (MALDI) $m / z[\mathrm{M}+\mathrm{H}]^{+}$calcd for $\mathrm{C}_{20} \mathrm{H}_{25} \mathrm{NO}_{2}, 312.1958$; found, 312.1960 .

\section{Acknowledgment}

This research has been supported by the Croatian Ministry of Science, Education and Sports, Grant Nos. 098-0982933-2936, 098-0982904-2927, and 098-0352851-2921.

\section{Supporting information}

Materials and methods, computational details, FT-IR measurements, NMR spectra of all compounds, mass spectra of $\mathbf{4 a - 4 e}$, and products of Bergman cyclization. This material is available free of charge via the Internet at http://pubs.acs.org.

\section{References}

1. (a) Smith, A. L.; Nicolaou, K. C. J. Med. Chem. 1996, 39, 2103- 2117, (b) Edo, K.; Mizugaki, M.; Koide, Y.; Seto, H.; Furihata, K.; Otake, N.; Ishida, N. Tetrahedron Lett. 1985, 26, 331- 334, (c) Lee, M. D.; Dunne, T. S.; Chang, C. C.; Ellestad, G. A.; Siegel, M. M.; Morton, G. O.; McGahren, W. J.; Borders, D. B. J. Am. Chem. Soc. 1987, 109, 3466- 3468, (d) Golik, J.; Clardy, J.; Dubay, G.; Groenwold, G.; Kawaguchi, H.; Konishi, M.; Krishnan, B.; Ohkuma, H.; Saitoh, K.; Doyle, T. W. J. Am. Chem. Soc. 1987, 109, 3461- 3462, (e) Konishi, M.; Ohkuma, H.; Tsuno, T.; Oki, T.; VanDuyne, G. D.; Clardy, J. J. Am. Chem. Soc. 1990, 112, 3715- 3716

2. Bergman, R. G. Acc. Chem. Res. 1973, 6, 25- 31

3. Guanti, G.; Riva, r. Org. Biomol. Chem. 2003, 1, 3967- 3976

4. Komano, K.; Shimamura, S.; Inoue, M.; Hirama, M. J. Am. Chem. Soc. 2007, 129, $14184-14186$

5. Ren, F.; Hogan, P. C.; Anderson, A. J.; Myers, A. J. Am. Chem. Soc. 2007, 129, 53815383

6. Desrat, S.; van de Weghe, P. J. Org. Chem. 2009, 74, 6728- 6734

7. Zhang, Y.; Petersen, J.; Wang, K. K. Tetrahedron 2008, 64, 1285- 1293

8. Hickenboth, C. R.; Rule, J. D.; Moore, J. S. Tetrahedron 2008, 64, 8435- 8448

9. Shain, J. C.; Khamrai, U. K.; Basak, A. Tetrahedron Lett. 1997, 34, 6067-6070, (b) Jones, G. B.; Plourde, G. W., II. Org. Lett. 2000, 2, 1757- 1759 
Gredičak M; Matanović I; Zimmermann B \& Jerić I. "Bergman Cyclization of Acyclic Amino Acid Derived Enediynes Leads to the Formation of 2,3-Dihydrobenzo[f]isoindoles", Journal of Organic Chemistry, Vol.75, No.18, pp. 6219-6228. DOI: 10.1021/jo101302n

10. Kar, M.; Basak, A.; Bhattacharjee, M. Bioorg. Med. Chem. Lett. 2005, 15, 5392- 5396, (b) Poloukhtine, A.; Popik, V. V. J. Org. Chem. 2006, 71, 7417- 7421

11. Bhattacharyya, S.; Pink, M.; Baik, M.; Zaleski, J. M. Angew. Chem., Int. Ed. 2005, 44, 592- 595, (b) Basak, A.; Mandal, S.; Bag, S. S. Chem. Rev. 2003, 103, 4077- 4094

12. (a) Kovalenko, S. V.; Alabugin, I. V. Chem. Commun. 2005, 1444- 1446, (b) Breiner, B.; Schlatterer, J. C.; Kovalenko, S. V.; Greenbaum, N. L.; Alabugin, I. V. Angew. Chem., Int. Ed. 2006, 45, 3666- 3670, (c) Breiner, B.; Schlatterer, J. C.; Kovalenko, S. V.; Greenbaum, N. L.; Alabugin, I. V. Proc. Natl. Acad. Sci. U.S.A. 2007, 104, $13016-$ 13021, (d) Yang, W.-Y.; Breiner, B.; Kovalenko, S. V.; Ben, C.; Singh, M.; LeGrand, S. N.; Sang, Q-X. A.; Strouse, G. F.; Copland, J. A.; Alabugin, I. J. Am. Chem. Soc. 2009, $131,11458-11470$

13. Dutta, S.; Basak, A.; Dasgupta, S. Bioorg. Med. Chem. 2009, 17, 3900- 3908

14. Fouad, F. S.; Wright, J. M.; Plourde, G., II; Purohit, A. D.; Wyatt, J. K.; El-Shafey, A.; Hynd, G.; Crasto, C. F.; Lin, Y.; Jones, G. B. J. Org. Chem. 2005, 70, 9789-9797

15. (a) Du, Y.; Creighton, C. J.; Yan, Z.; Gauthier, D. A.; Dahl, J. P.; Zhao, B.; Belkowski, S. M.; Reitz, A. B. Bioorg. Med. Chem. 2005, 13, 5936- 5948, (b) Kaiser, J.; van Esseveldt, B. C. J.; Segers, M. J. A.; van Delft, F. L.; Smits, J. M. M.; Butterworth, S.; Rutjes, F. P. J. T. Org. Biomol. Chem. 2009, 7, 695- 705

16. Gredičak, M.; Kolonić, A.; Jerić, I. Amino Acids 2008, 35, 185- 194

17. Zeidan, T.; Kovalenko, S. V.; Manoharan, M.; Alabugin, I. V. J. Org. Chem. 2006, 71, 962- 975

18. Zimmermann, B.; Baranović, G. Appl. Spectrosc. 2009, 63, 1152- 1161

19. Nicolaou, K. C.; Smith, A. L.; Yue, E. W. Proc. Natl. Acad. Sci. U.S.A. 1993, 90, 58815888

20. Bergman cyclization of $\mathbf{4 e}$, due to the high onset temperature, was performed in $N$ methyl-pyrrolidone (NMP); $\Delta$ marks the $T_{\max }$ obtained by the FT-IR for selected derivative.

21. Johnson, J. P.; Bringley, D. A.; Wilson, E. E.; Lewis, K. D.; Beck, L. W.; Matzger, A. J. J. Am. Chem. Soc. 2003, 125, 14708- 14709

22. Kumar Roy, S.; Basak, A. Chem. Commun. 2006, 1646- 1648

23. Pichon, N.; Harrison-Marchand, A.; Mailliet, P.; Maddaluno, J. J. Org. Chem. 2004, 69, 7220- 7227

24. Claessens, S.; Jacobs, J.; Aeken, S. V.; Tehrani, K. A.; De Kimpe, N. J. Org. Chem. 2008, $73,7555-7559$

25. It is worth noting that we tried to "catch" the Bergman product before elimination by closer monitoring of the reaction. 4a was dissolved in DMF with 100 equiv of 1,4-CHD; aliquots were placed into melting point tubes, frozen by liquid nitrogen, degassed under high vacuum, sealed, and placed into an oil bath at $160{ }^{\circ} \mathrm{C}$. Capillaries were withdrawn in different time periods and analyzed by ESI MS. However, only disappearance of $4 \mathbf{a}(\mathrm{m} / \mathrm{z}$ $385)$ and appearance of $\mathbf{6 a}(\mathrm{m} / \mathrm{z} 270)$ was observed.

26. Becke, A. D. Phys. Rev. A 1988, 38, 3098- 3100, (b) Lee, C.; Yang, W.; Parr, R. G. Phys. Rev. B 1988, 37, 785- 789, (c) Vosko, S. H.; Wilk, L.; Nusair, M Can. J. Phys. 
Gredičak M; Matanović I; Zimmermann B \& Jerić I. "Bergman Cyclization of Acyclic Amino Acid Derived Enediynes Leads to the Formation of 2,3-Dihydrobenzo[f]isoindoles", Journal of Organic Chemistry, Vol.75, No.18, pp. 6219-6228. DOI: 10.1021/jo101302n

1980, 58, 1200- 1211, (d) Stephens, P. J.; Devlin, F. J.; Chabalowski, C. F.; Frisch, M. J. J. Phys. Chem. 1994, 98, 11623- 11627

27. (a) Becke, A. D. J. Chem. Phys. 1996, 104, 1040- 1046, (b) Lee, C.; Yang, W.; Parr, R. G. Phys. Rev. B 1988, 37, 785- 789

28. Frisch, M. J.; Gaussian 03, revision B.05; Gaussian, Inc.: Pittsburgh, PA, 2003.

29. Zeidan, T. A; Manoharan, M.; Alabugin, I. V. J. Org. Chem. 2006, 71, 954- 961

30. Pickard, F. C., IV; Shepherd, R. L.; Gillis, A. E.; Dunn, M. E; Feldgus, S.; Kirschner, K. N.; Shields, G. C.; Manoharan, M.; Alabugin, I. V. J. Phys. Chem. A 2006, 110, $2517-$ 2526

31. Schreiner, P. R.; Navarro-Vazquez, A.; Prall, M. Acc. Chem. Res. 2005, 38, 29- 37

32. Inoue, M.; Usuki, T.; Lee, N.; Hirama, M.; Tanaka, T.; Hosoi, F.; Ohie, S.; Otani, T. J. Am. Chem. Soc. 2006, 128, 7896- 7903

33. Baroudi, A.; Mauldin, J.; Alabugin, I. V. J. Am. Chem. Soc. 2010, 132, 967-979 